\title{
Original paper \\ Garnet-forming reactions in calc-silicate rocks from the Polička Unit, Svratka Unit and SE part of the Moldanubian Zone
}

\author{
David BURIÁNEK*, Jaroslava PERTOLDOVÁ \\ Czech Geological Survey, Klárov 3, 11821 Prague 1, Czech Republic; david.burianek@geology.cz \\ * Corresponding author
}

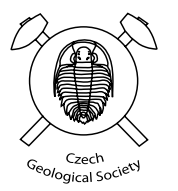

Three main Variscan tectono-metamorphic units with distinct metamorphic evolution are present at the eastern boundary of the Bohemian Massif: Moldanubian Zone (MZ), Svratka Unit (SU) and Polička Unit (PU). All these metamorphic complexes contain calc-silicate rocks, which occur as bodies, layers or nodules within gneisses, mica schists, marbles, amphibolites or skarns. Calc-silicate rocks consist of quartz, plagioclase, diopside, titanite and sometimes amphibole, scapolite, garnet, minerals of the epidote group, K-feldspar and calcite.

Two groups of calc-silicate rocks are distinguished according to the presence/absence of garnet. The appearance of garnet is the result of continuous reactions among Fe-Ca-Al minerals. The dominant garnet-producing reaction calcite + quartz + clinozoisite $=$ garnet $+\mathrm{H}_{2} \mathrm{O}+5 \mathrm{CO}_{2}$ depends on the $\mathrm{P}-\mathrm{T}$ conditions, $\mathrm{X}_{\mathrm{CO}_{2}}$ in the coexisting metamorphic fluids and bulk rock chemistry.

Phase relations and mineral compositions document a polymetamorphic history of the calc-silicate rocks. Calc-silicate rocks from the middle subunit of the PU have been affected by LP-MT metamorphism $\mathrm{M}_{1}$ and strongly overprinted by a temperature peak of the Variscan regional metamorphism under amphibolite-facies conditions $\left(\mathrm{M}_{2} ; 560-650{ }^{\circ} \mathrm{C}\right.$ and 5-7 kbar). Calc-silicate rocks of the MZ, SU, and lower subunit of the PU reflect post-peak metamorphic decompression $\left(\mathrm{M}_{2}\right)$ after MP-HT metamorphism $\left(\mathrm{M}_{1}\right)$. Metamorphic P-T conditions of $640-680{ }^{\circ} \mathrm{C}$ and 6-7 kbar obtained for the calc-silicate rocks from the $\mathrm{MZ}$ and $\mathrm{SU}$ correspond to data from adjacent metapelites $\left(\mathrm{M}_{2}\right)$ and are similar to the $\mathrm{P}-\mathrm{T}$ conditions for metapelites from the lower subunit of the PU. The Variscan regional metamorphism in all the studied units was followed by younger, greenschist-facies metamorphism $\left(\mathrm{M}_{3}\right)$.

The temperature, pressure and metamorphic fluids composition were estimated from the mineral assemblages of the calc-silicate rocks and surrounding metapelites. The observed mineral reaction sequences require very low $\mathrm{X}_{\mathrm{CO} 2}$ values for calc-silicate nodules from the middle subunit of the $\mathrm{PU}$ and variable $\mathrm{X}_{\mathrm{CO} 2}$ values for the rest of the studied calc-silicate rocks. These variations in fluid composition were controlled by the size of the bodies, their bulk rock chemistry and/or the presence of carbonates in the surrounding rock complexes. The metamorphic assemblages with coexisting garnet and epidote group minerals from calc-silicate rocks are widespread in all the tectono-metamorphic units at the eastern margin of the Bohemian Massif. Appearance of comparable mineral assemblages in the rocks with variable geological evolution can be explained by the higher activity of hydrous fluids during metamorphic reactions in the surrounding metapelites at 550-680 ${ }^{\circ} \mathrm{C}$ and 5-7 kbar. The bulk rock chemistry and mineralogy of the calc-silicate rocks indicate that they were derived from silica-rich calcareous protoliths, such as marls or altered tuffs.

Keywords: calc-silicate rocks, Polička Unit, Svratka Unit, Moldanubian Zone, P-T conditions, Czech Republic

Received: 11 March 2009; accepted 25 September 2009; handling editor: J. Konopásek

The online version of this article (http://dx.doi.org/10.3190/jgeosci.051) contains supplementary electronic material.

\section{Introduction}

Calc-silicate rocks frequently form small bodies or layers in metamorphosed volcano-sedimentary sequences. Their bulk rock chemistry can be used as a good lithostratigraphic marker. On the other hand, the mineral assemblage of calc-silicate rocks is relatively sensitive to the water content in metamorphic fluids and can be used as an important indicator of changes in fluid composition during the metamorphic evolution (e.g. Ferry 1991, 1994). These rocks usually recorded local equilibrium and often show large differences in reaction progress from layer to layer (Baumgartner and Ferry 1991).
The calc-silicate rocks at the eastern margin of the Bohemian Massif (in the adjacent Polička and Svratka units, as well as in the Moldanubian Zone) exhibit a number of similarities in their petrology and mineralogy. The metamorphic assemblage $\mathrm{Cpx}+\mathrm{Pl}+\mathrm{Czo} \pm \mathrm{Grt} \pm \mathrm{Scp} \pm \mathrm{Cal}$ \pm Qtz is widespread in the studied area and it is differs from the metamorphic assemblages present in the hightemperature contact aureoles (Owens 2000) or in terrains affected by granulite-facies metamorphism (Shaw and Arima 1996; Klemd et al. 2003; Dasgupta and Pal 2005). Epidote group minerals coexisting with garnet are known from many localities of calc-silicate rocks in all studied units in spite of the largely independent metamorphic 
evolution of these crustal domains (Verner et al. 2009). Variscan regional metamorphism in the Moldanubian Zone and Svratka Unit can be interpreted as a polyphase evolution from high-pressure and temperature to mediumpressure and temperature (HP-HT to MP-MT) metamorphic conditions (Tajčmanová et al. 2001, 2006; Melichar et al. 2008). On the other hand, rocks from the Polička Unit experienced an anticlockwise $\mathrm{P}-\mathrm{T}$ path, from older LP-MT to younger MP-MT regional metamorphism (Buriánek et al. 2009a).

Calc-silicate rocks preserve important clues to the metamorphic evolution of these three units. In general, the calc-silicate rocks occur as thin layers, bodies and nodules in association with metapelites, metapsammites, amphibolites, marbles or skarns. They may provide supplementary information about the evolution of the studied units, because they reflect changes in the $\mathrm{P}-\mathrm{T}$-fluid history better than the surrounding rocks.

\section{Geological setting}

\subsection{Polička Unit}

The Polička Unit (PU) is situated in the E part of the Bohemian Massif and in the classic concept of Mísař et al. (1983) it belongs to the Bohemicum. The main part of this unit is exposed in a NW-SE oriented belt (Fig. 1). Generally, the PU is in contact with the metamorphic rocks of the Svratka Unit to the SW, and the Lower Palaeozoic volcano-sedimentary complex of the Hlinsko Unit to the NW. The both boundaries were subsequently tectonically reworked by younger, normal faults (Melichar 1993). Sediments of the Bohemian Cretaceous basin cover the rocks of PU to the NE.

The PU is built by three main lithotectonic sequences (Melichar 1993) intruded by several magmatic bodies. The variegated lower subunit forms the base of the PU and it is overlain by a monotonous middle subunit and the topmost metasedimentary upper subunit in the tectonic hanging wall. All subunits are elongated parallel with the regional metamorphic foliation which is NW-SE striking and dipping at medium angle towards the NE in most of the PU.

The variegated lower subunit is dominantly exposed along the boundary with the underlying Svratka Unit. It is represented by medium-grained biotite and muscovite-biotite gneisses with strongly deformed bodies of metagranitoids, augen gneisses, amphibolites, marbles and calc-silicate rocks. Elongated bodies of calc-silicate rocks are situated in the lower subunit along the boundary between PU and SU. The lower subunit has been referred to as "tectonic melange" (Buriánek et al. 2009b). This is based on a set of geological observations, of which the most convincing seems to be a retrogressive change in metamorphic grade from the granulite-facies in the south of the lower subunit to the amphibolite-facies recorded from the metapelites in its northern part (Buriánek et al. 2009a). The metamorphic conditions of $c .760-800^{\circ} \mathrm{C}$ and $7 \mathrm{kbar}$ (Buriánek et al. 2009b) were calculated for the garnet-biotite augen gneisses in the northern part of the lower subunit. The granulites from the lower subunit (Vír granulite body) preserved the P-T conditions of $850-900^{\circ} \mathrm{C}$ and $13-14$ kbar (Tajčmanová et al. 2005). Granulite-facies metamorphic mineral association is partly replaced by decompression-related, retrograde mineral assemblage formed at $c .600^{\circ} \mathrm{C}$ and $6-8 \mathrm{kbar}$ (Štoudová et al. 1999). The metapelites and amphibolites surrounding granulite indicate amphibolite-facies metamorphic conditions and locally partial melting (Štoudová et al. 1999). Amphibolites with MORB-like geochemistry form a narrow belt along the boundary of the lower and middle subunits of the PU (Melichar and Hanžl 1997). A second belt of amphibolites rims the contact of the PU with the Svratka Unit (Fig. 1).

The middle subunit is built by monotonous complex of medium-grained paragneisses (metagreywackes, metapelites, rare metaconglomerates) with locally abundant calc-silicate nodules up to $0.5 \mathrm{~m}$ in size. The middle subunit recorded an anticlockwise metamorphic evolution. Relics of the oldest LP-MT metamorphism $\mathrm{M}_{1}$ are preserved mainly in the northernmost part of the unit (Buriánek et al. 2009a). Later $\mathrm{M}_{2}$ metamorphism at 580$680^{\circ} \mathrm{C}$ and 5-7 kbar affected a substantial part of the PU. This metamorphic event was, in the vicinity of tonalite bodies and in the southern part of the PU, accompanied by partial melting of the metapelites.

The upper subunit is represented by a metasedimentary sequence consisting of micaschists with quartzite and paragneiss intercalations (Melichar 1993).

During the Variscan orogeny, the PU was intruded by a number of intrusive bodies. The following magmatic suites were distinguished by Buriánek et al. (2003): (1) the earliest basic suite of gabbros and diorites, (2) tonalite suite and (3) the latest granite suite.

\subsection{Svratka Unit}

The Svratka Unit (SU) represents a mature continental crustal segment consisting of metagranite bodies alternating with layers of migmatites, mica schists and paragneisses. Minor lithologies are represented by bodies of marbles, calc-silicate rocks, amphibolites and skarns (Melichar et al. 2008; Hanžl et al. 2008a). The Svratka metagranites dated at $c$. $515 \mathrm{Ma}$ were emplaced during the Cambro-Ordovician magmatic event (Schulmann et al. 2005) into the migmatitized Neoproterozoic to Cambrian lower crust (Buriánek 2008). Relics of the oldest 


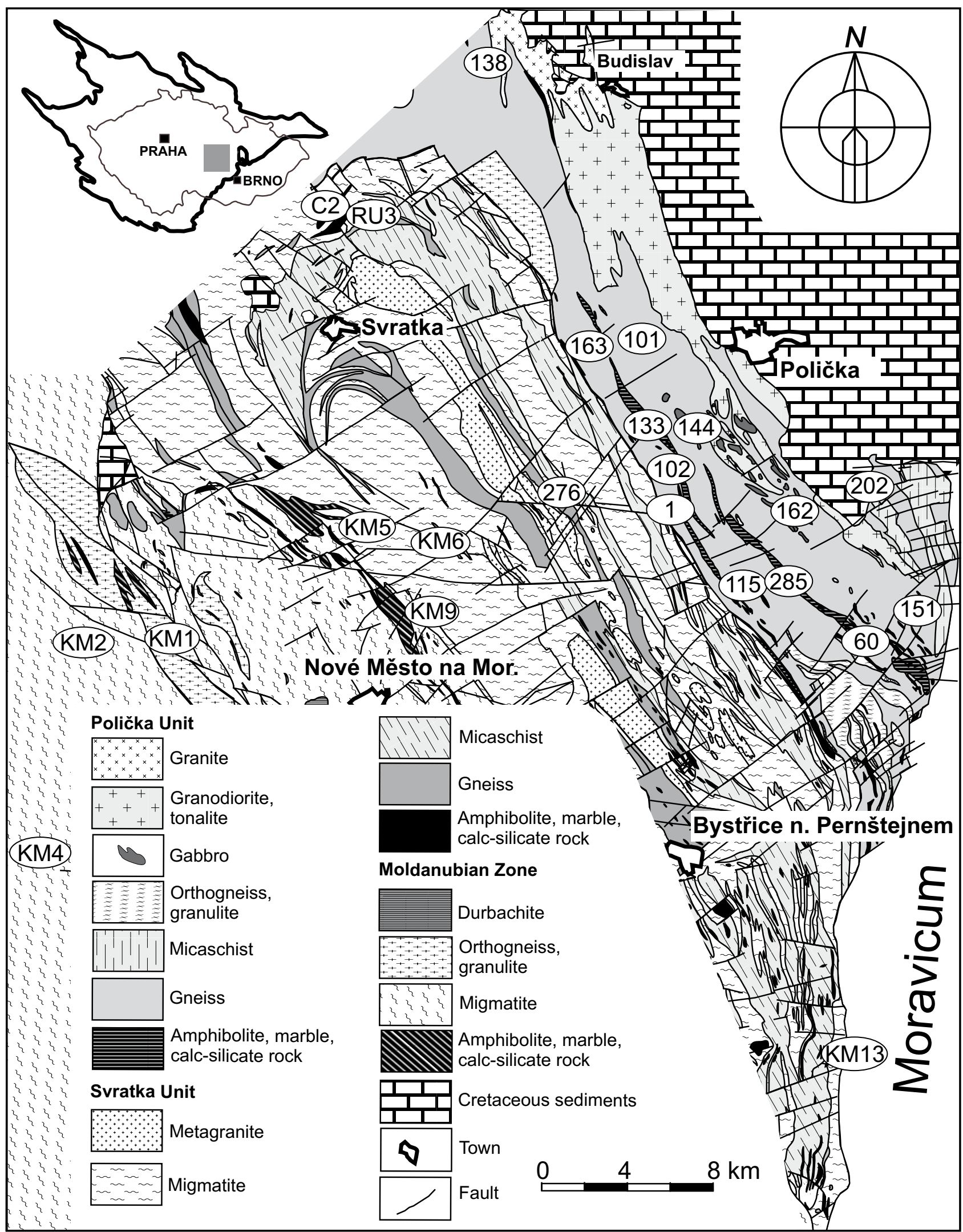

Fig. 1 Simplified geological maps of the Svratka Unit, Polička Unit and eastern part of the Moldanubian Zone at the eastern margin of the Bohemian Massif with sample locations (modified from: Stárková and Macek 1994; Mísař et al. 1995; Stárková et al. 1996, 1998; Hanžl et al. 2006, 2008a, b; Melichar et al. 2008; Mrázová et al. 2008; Buriánek et al. 2009a). 
HP (c. 12 kbar) metamorphism were identified in the skarns (Pertoldová 1986).

During the Variscan Orogeny, the Svratka Unit was affected by regional metamorphism, which attained amphibolite-facies conditions $\left(c .640-670^{\circ} \mathrm{C}\right.$ at $c .7-8 \mathrm{kbar}$; Pitra and Guiraud 1996; Buriánek and Čopjaková 2008) followed by decompression and cooling to $c .580-650{ }^{\circ} \mathrm{C}$ and c. 6 kbar (Buriánek and Čopjaková 2008). Variscan deformation of granitoids and migmatites resulted in sub-solidus deformation of primary quartz and feldspar crystals (Zavřelová et al. 2006; Buriánek et al. 2009c).

\subsection{Moldanubian Zone}

The Moldanubian Zone (MZ) is the most internal part of the Variscan orogenic belt. The following three units have been assembled during the Variscan orogeny and modified by several deformation and metamorphic events (e.g. Franke 2000; Verner et al. 2009). Migmatitized $\mathrm{K}$-feldspar \pm cordierite-sillimanite-biotite paragneisses represent a major rock type of the structurally lowermost Monotonous Unit. The Varied Unit overlies the Monotonous Unit and contains biotite-sillimanite paragneisses with numerous intercalations of marbles, quartzites, mafic and felsic metavolcanic rocks (Kachlík 1999). In general, the estimated PT conditions of regional metamorphism in rocks of the Monotonous and Varied units are in the range of $\mathrm{T}=630-720^{\circ} \mathrm{C}$ and $\mathrm{P}=3-10 \mathrm{kbar}$ (Vrána et al. 1995; Petrakakis 1997; Racek et al. 2006).

The Gföhl Unit forms structurally the uppermost part of the MZ. Therein prevailing quartzofeldspathic crustal rocks (migmatites, metagranites and granulites) include bodies of mafic HT-HP rocks (peridotites, eclogites). Metamorphism of the Gföhl Unit is characterized by early eclogite facies: $\mathrm{T}=\sim 850-1000^{\circ} \mathrm{C}$ and $\mathrm{P}=\sim 15-20 \mathrm{kbar}$, followed by granulite-facies re-equilibration (O'Brien and Vrána 1995), with subsequent retrograde metamorphism at $\mathrm{T}=c .600-800^{\circ} \mathrm{C}$ and $\mathrm{P}=c .6-8 \mathrm{kbar}$ (e.g., Štípská et al. 2004; Tajčmanová et al. 2006). According to Drahota et al. (2005), regionally metamorphosed skarns from the Gföhl Unit reflect post-peak metamorphic decompression after high-pressure - high-temperature regional metamorphism $\left(c .800^{\circ} \mathrm{C}\right.$ and $\left.12 \mathrm{kbar}\right)$ and younger regional metamorphism $\left(670^{\circ} \mathrm{C}, 6-8 \mathrm{kbar}\right)$ accompanied by intrusions of granitic bodies.

The calc-silicate rocks of the MZ are present mainly in the Varied and Gföhl units, often together with skarns or marbles. Marbles in the eastern part of the Varied Unit provide evidence for a clockwise metamorphic $\mathrm{P}-\mathrm{T}$ path from amphibolite- to greenschist-facies conditions (Novák 1989). The older metamorphic assemblage $M_{1}$ with phlogopite and tremolite is typically overprinted by younger HT-LP metamorphism $\mathrm{M}_{2}$ characterized by mineral assemblages with forsterite, spinel, chlorite and locally clinohumite (Chu). The estimated maximum metamorphic conditions for $\mathrm{M}_{1}$ event are $\mathrm{T}=660^{\circ} \mathrm{C}$ and $\mathrm{P}=6 \mathrm{kbar}$ and the $\mathrm{M}_{2}$ metamorphism corresponded to $\mathrm{P}$ $=2 \mathrm{kbar}, \mathrm{T}=550^{\circ} \mathrm{C}$ and $\mathrm{X}_{\mathrm{CO} 2}<0.1$ (Novák 1989).

\section{Methods}

We have selected 20 samples representing different lithological and structural positions, metamorphic evolution, mineralogical and textural characteristics (Tab. 1). Significant variations in the chemical composition of mineral phases between different samples might be related to differences in the bulk-rock composition or distinct metamorphic evolution. Mineral analyses were performed on the Cameca SX-100 electron microprobe at the Department of Geological Sciences, Faculty of Science, Masaryk University in Brno. The measurements were carried out in a wave dispersion mode under the following conditions: $15 \mathrm{kV}$ acceleration voltage, $5 \mu \mathrm{m}$ electron beam diameter, $30 \mathrm{nA}$ current and $20 \mathrm{~s}$ integration time. Augite $(\mathrm{Si}, \mathrm{Mg})$, orthoclase $(\mathrm{K})$, jadeite $(\mathrm{Na})$, chromite $(\mathrm{Cr})$, almandine $(\mathrm{Al})$, andradite $(\mathrm{Fe}, \mathrm{Ca})$, rhodonite $(\mathrm{Mn})$, and $\mathrm{TiO}(\mathrm{Ti})$ were used as standard. The crystallochemical formulae of scapolite were calculated on the basis of $12(\mathrm{Si}+\mathrm{Al})$ cations. Scapolite compositions are expressed in per cent of the meionite end member $\mathrm{Me}=100 \mathrm{Ca} /(\mathrm{Ca}+\mathrm{Na}+\mathrm{K})$ and equivalent anorthite content EqAn $=(100 *(\mathrm{Al}-3) / 3)($ Ellis 1978). Minerals of the epidote group were recalculated to 12.5 oxygen atoms. The crystallochemical formulae of feldspars were recalculated to 8 oxygen atoms and of micas to 22 oxygen atoms. The crystallochemical formulae of garnet were obtained on the basis of 12 oxygen atoms. Ferric iron is recalculated based on charge balance and stoichiometry. The amphibole formulae were calculated on the basis of 23 oxygen atoms; all analyses can be classified as calcic amphiboles (Leake et al. 1997). The $\mathrm{Fe}^{2+} / \mathrm{Fe}^{3+}$ ratios were estimated on the basis of cation total of 13 excluding $\mathrm{Ca}$, $\mathrm{Na}, \mathrm{K}(13 \mathrm{eCNK})$. The crystallochemical formulae of titanite were obtained on the basis of $4 \mathrm{Si}$. Pyroxene is classified according to Morimoto et al. (1988); formulae were calculated on the basis of 4 cations and method for estimating ferric iron given by Droop (1987). The abbreviations of mineral names used in the text correspond to Kretz (1983).

Samples at least 3-4 kg in weight were used for the whole-rock chemical analyses. Major and trace elements were determined at Acme Analytical Laboratories, Ltd., Vancouver, Canada. Major oxides were analysed by the ICP-MS method. Loss on ignition (LOI) was calculated from the weight difference after ignition at $1000^{\circ} \mathrm{C}$. The rare earth and other trace elements were analysed by INAA and ICP-MS following a $\mathrm{LiBO}_{2}$ fusion. Geochemi- 
Tab. 1 List of studied samples and their mineral assemblages from Moldanubian Zone (MZ), Svratka (SU) and Polička units (PU)

\begin{tabular}{|c|c|c|c|c|c|c|}
\hline Sample & Unit & Longitude $\left({ }^{\circ} \mathrm{E}\right)$ & Latitude $\left({ }^{\circ} \mathrm{N}\right)$ & Locality & Wall rocks & Mineral assemblage \\
\hline 115 & PU & $16^{\circ} 16^{\prime} 50.30^{\prime \prime}$ & $49^{\circ} 37^{\prime} 17.01^{\prime \prime}$ & Ubušín & gneiss & $\mathrm{Pl}+\mathrm{Cpx}+\mathrm{Qtz} \pm \mathrm{Grt} \pm \mathrm{Amp}+\mathrm{Ttn}+\mathrm{Kfs}$ \\
\hline 133 & PU & $16^{\circ} 12^{\prime} 41.78^{\prime \prime}$ & $49^{\circ} 40^{\prime} 27.79^{\prime \prime}$ & Lačnov & gneiss & $\mathrm{Qtz}+\mathrm{Cpx}+\mathrm{Pl}+\mathrm{Ep}+\mathrm{Amp}+\mathrm{Cal}+\mathrm{Ttn}+\mathrm{Chl}$ \\
\hline 163 & PU & $16^{\circ} 11^{\prime} 60.70^{\prime \prime}$ & $49^{\circ} 42^{\prime} 60.86^{\prime \prime}$ & Telecí & amphibolite & $\mathrm{Qtz}+\mathrm{Cpx}+\mathrm{Pl}+\mathrm{Ep}+\mathrm{Amp}+\mathrm{Cal}+\mathrm{Ttn}+\mathrm{Chl}+\mathrm{Kfs}$ \\
\hline 102 & PU & $16^{\circ} 13^{\prime} 34.56^{\prime \prime}$ & $49^{\circ} 39^{\prime} 51.15^{\prime \prime}$ & Borovnice & amphibolite & $\mathrm{Qtz}+\mathrm{Cpx}+\mathrm{Pl}+\mathrm{Kfs}+\mathrm{Czo}+\mathrm{Amp}+\mathrm{Ttn}$ \\
\hline 285 & PU & $16^{\circ} 17^{\prime} 56.71^{\prime \prime}$ & $49^{\circ} 37^{\prime} 37.75^{\prime \prime}$ & Nedvězí & amphibolite & $\mathrm{Qtz}+\mathrm{Pl}+\mathrm{Cpx}+\mathrm{Ttn}+\mathrm{Scp}+\mathrm{Amp}$ \\
\hline 60 & PU & $16^{\circ} 21^{\prime} 27.89^{\prime \prime}$ & $49^{\circ} 36^{\prime} 35.97^{\prime \prime}$ & Nyklovice & amphibolite & $\mathrm{Qtz}+\mathrm{Pl}+\mathrm{Cpx}+\mathrm{Amp}+\mathrm{Ttn} \pm \mathrm{Scp} \pm \mathrm{Czo} \pm \mathrm{Grt}$ \\
\hline 1 & PU & $16^{\circ} 14^{\prime} 50.90^{\prime \prime}$ & $49^{\circ} 38^{\prime} 44.78^{\prime \prime}$ & Sedliště & marble & $\mathrm{Qtz}+\mathrm{Pl}+\mathrm{Cpx}+\mathrm{Amp}+\mathrm{Ttn} \pm \mathrm{Scp} \pm \mathrm{Bt} \pm \mathrm{Cal} \pm \mathrm{Kfs} \pm \mathrm{Czo}$ \\
\hline 151 & PU & $16^{\circ} 21^{\prime} 53.63^{\prime \prime}$ & $49^{\circ} 37^{\prime} 80.84^{\prime \prime}$ & Hartmanice & gneiss & $\mathrm{Grt}+\mathrm{Cpx}+\mathrm{Pl}+\mathrm{Qtz}+\mathrm{Czo} \pm \mathrm{Cal}$ \\
\hline 202 & PU & $16^{\circ} 20^{\prime} 43.24^{\prime \prime}$ & $49^{\circ} 39^{\prime} 45.82^{\prime \prime}$ & Dol. Jedlová & gneiss & $\mathrm{Cpx}+\mathrm{Pl}+\mathrm{Qtz}+\mathrm{Czo}+\mathrm{Ttn} \pm \mathrm{Tur} \pm \mathrm{Grt}$ \\
\hline 162 & PU & $16^{\circ} 18^{\prime} 16.67^{\prime \prime}$ & $49^{\circ} 39^{\prime} 20.58^{\prime \prime}$ & Hor. Jedlová & gneiss & $\mathrm{Pl}+\mathrm{Cal}+\mathrm{Qtz} \pm \mathrm{Cpx} \pm \mathrm{Amp}+\mathrm{Ttn}$ \\
\hline 101 & PU & $16^{\circ} 12^{\prime} 47.65^{\prime \prime}$ & $49^{\circ} 41^{\prime} 53.71^{\prime \prime}$ & Sádek & gneiss & $\mathrm{Cpx}+\mathrm{Grt}+\mathrm{Pl}+\mathrm{Qtz}+\mathrm{Czo} \pm \mathrm{Cal}+\mathrm{Ttn}$ \\
\hline 144 & PU & $16^{\circ} 13^{\prime} 80.09^{\prime \prime}$ & $49^{\circ} 40^{\prime} 51.88^{\prime \prime}$ & Sádek & gneiss & $\mathrm{Cpx}+\mathrm{Pl}+\mathrm{Qtz}+\mathrm{Grt}+\mathrm{Czo} \pm \mathrm{Cal}+\mathrm{Ttn}$ \\
\hline 138 & PU & $16^{\circ} 60^{\prime} 50.24^{\prime \prime}$ & $49^{\circ} 48^{\prime} 12.29^{\prime \prime}$ & Proseč & gneiss & $\mathrm{Pl}+\mathrm{Cpx}+\mathrm{Qtz}+\mathrm{Cal}+\mathrm{Ttn}$ \\
\hline 276 & SU & $16^{\circ} 10^{\prime} 43.24^{\prime \prime}$ & $49^{\circ} 38^{\prime} 28.98^{\prime \prime}$ & Javorek & marble & $\mathrm{Cpx}+\mathrm{Pl}+\mathrm{Amp}+\mathrm{Qtz}+\mathrm{Czo}+\mathrm{Ttn}$ \\
\hline $\mathrm{C} 2$ & SU & $16^{\circ} 20^{\prime} 24.57^{\prime \prime}$ & $49^{\circ} 45^{\prime} 60.79^{\prime \prime}$ & Čachnov-1 & skarn & $\mathrm{Amp}+\mathrm{Ep}+\mathrm{Cpx}+\mathrm{Pl}+\mathrm{Qtz}+\mathrm{Czo}+\mathrm{Ttn}$ \\
\hline $\mathrm{C} 2 \mathrm{a}$ & SU & $16^{\circ} 20^{\prime} 24.57^{\prime \prime}$ & $49^{\circ} 45^{\prime} 60.79^{\prime \prime}$ & Čachnov-21 & skarn & $\mathrm{Cpx}+\mathrm{Pl}+\mathrm{Scp}+\mathrm{Amp}+\mathrm{Grt}+\mathrm{Ep}+\mathrm{Ttn}$ \\
\hline $\mathrm{C} 2 \mathrm{~b}$ & SU & $16^{\circ} 20^{\prime} 24.57^{\prime \prime}$ & $49^{\circ} 45^{\prime} 60.79^{\prime \prime}$ & Čachnov-22 & skarn & $\mathrm{Cpx}+\mathrm{Pl}+\mathrm{Grt}+\mathrm{Ep}$ \\
\hline DB2 & SU & $16^{\circ} 20^{\prime} 24.57^{\prime \prime}$ & $49^{\circ} 45^{\prime} 60.79^{\prime \prime}$ & Čachnov & skarn & $\mathrm{Grt}+\mathrm{Plg}+\mathrm{Cpx}+\mathrm{Ep}+\mathrm{Czo}+\mathrm{Ttn}$ \\
\hline RU3 & SU & $16^{\circ} 40^{\prime} 34.29^{\prime \prime}$ & $49^{\circ} 44^{\prime} 45.48^{\prime \prime}$ & Ruda u Č.-3 & skarn & $\mathrm{Grt}+\mathrm{Cpx}+\mathrm{Pl}+\mathrm{Ttn}+\mathrm{Ap}+\mathrm{Aln}+\mathrm{Opq}$ \\
\hline KM5 & SU & $16^{\circ} 10^{\prime} 31.47^{\prime \prime}$ & $49^{\circ} 37^{\prime} 48.79^{\prime \prime}$ & Fryšava & skarn & $\mathrm{Cpx}+\mathrm{Ep}+\mathrm{Grt}+\mathrm{Pl}$ \\
\hline KM4a & SU & $15^{\circ} 56^{\prime} 54.54 "$ & $49^{\circ} 21^{\prime} 23.86^{\prime \prime}$ & Hrbov & skarn & $\mathrm{Ep}+\mathrm{Pl}+\mathrm{Cpx}+\mathrm{Ttn}$ \\
\hline KM4b & SU & $15^{\circ} 56^{\prime} 54.54^{\prime \prime}$ & $49^{\circ} 21^{\prime} 23.86^{\prime \prime}$ & Hrbov & skarn & $\mathrm{Amp}+\mathrm{Bt}+\mathrm{Pl}+\mathrm{Ilm}+\mathrm{Cpx}+\mathrm{Ttn}$ \\
\hline KM6 & SU & $16^{\circ} 40^{\prime \prime} 70.42^{\prime \prime}$ & $49^{\circ} 37^{\prime} 33.06^{\prime \prime}$ & Kadov & skarn & $\mathrm{Cpx}+\mathrm{Ep}+\mathrm{Grt}+\mathrm{Pl}$ \\
\hline KM13 & SU & $16^{\circ} 19^{\prime} 37.18^{\prime \prime}$ & $49^{\circ} 27^{\prime} 26.69^{\prime \prime}$ & Nedvědice & marble & $\mathrm{Ep}+\mathrm{Pl}+\mathrm{Grt}+\mathrm{Cpx}+\mathrm{Pl}$ \\
\hline KM9 & $\mathrm{MZ}$ & $16^{\circ} 50^{\prime} 33.45^{\prime \prime}$ & $49^{\circ} 36^{\prime} 90.46^{\prime \prime}$ & Studnice-A & marble & $\mathrm{Amp}+\mathrm{Ep}+\mathrm{Pl}+\mathrm{Kfs}+\mathrm{Cpx}$ \\
\hline KM9b & $\mathrm{MZ}$ & $16^{\circ} 50^{\prime} 33.45^{\prime \prime}$ & $49^{\circ} 36^{\prime} 90.46^{\prime \prime}$ & Studnice-B & marble & $\mathrm{Amp}+\mathrm{Bt}+\mathrm{Cal}+\mathrm{Pl}+\mathrm{Kfs}+\mathrm{Cpx}+\mathrm{Ttn}$ \\
\hline KM1 & $\mathrm{MZ}$ & $15^{\circ} 54^{\prime} 53.86^{\prime \prime}$ & $49^{\circ} 36^{\prime} 60.98^{\prime \prime}$ & Polnička & migmatite & $\mathrm{Ep}+\mathrm{Kfs}+\mathrm{Pl}+\mathrm{Cpx}+\mathrm{Ttn}$ \\
\hline KM3 & $\mathrm{MZ}$ & $15^{\circ} 51^{\prime} 30.78^{\prime \prime}$ & $49^{\circ} 35^{\prime} 10.51^{\prime \prime}$ & Vepřová-3 & skarn & $\mathrm{Amp}+\mathrm{Grt}+\mathrm{Pl}+\mathrm{Cpx}+\mathrm{Ttn} \pm \mathrm{Czo} \pm \mathrm{Scp}$ \\
\hline KM2 & $\mathrm{MZ}$ & $15^{\circ} 51^{\prime} 30.78^{\prime \prime}$ & $49^{\circ} 35^{\prime} 10.51^{\prime \prime}$ & Vepřová-2 & skarn & $\mathrm{Amp}+\mathrm{Bt}+\mathrm{Pl}+\mathrm{Kfs}+\mathrm{Cpx}+\mathrm{Ttn}$ \\
\hline
\end{tabular}

cal data were recalculated using the GCDkit software package (Janoušek et al. 2006).

The THERMOCALC program (Powell and Holland 1988; version 3.3, tc330) was employed to calculate the $\mathrm{P}-\mathrm{T}$ conditions in the metapelites and garnet-rich calcsilicate rocks of all crystalline complexes. It was run in the average $\mathrm{P}-\mathrm{T}$ mode using the data set from 8 December 1997 and activities from the AX program (Holland and Powell 1998). The principal reactions were calculated in the five-component $\mathrm{CaO}-\mathrm{Al}_{2} \mathrm{O}_{3}-\mathrm{SiO}_{2}-\mathrm{CO}_{2}-\mathrm{H}_{2} \mathrm{O}$ system from the low-variance assemblage activity-corrected mineral end-members calcite + clinozoisite + quartz + grossular + anorthite + wollastonite $+\mathrm{H}_{2} \mathrm{O}+\mathrm{CO}_{2}$. Clinopyroxene and tremolite have not been considered (Harley and Buick 1992).

The P-T-fluid histories of calc-silicate rocks are constrained through interpretation of reaction textures based on phase diagram (pseudosection) for model systems
CMFASNCH ( $\mathrm{CaO}-\mathrm{MgO}-\mathrm{FeO}-\mathrm{Al}_{2} \mathrm{O}_{3}-\mathrm{SiO}_{2}-\mathrm{Na}_{2} \mathrm{O}-$ $\left.\mathrm{CO}_{2}-\mathrm{H}_{2} \mathrm{O}\right)$. The T- $\mathrm{X}_{\mathrm{CO} 2}$ pseudosections for samples 101 (PU) and $\mathrm{C} 2(\mathrm{SU})$ have been calculated with the program PERPLEX (Connolly 2005) with the thermodynamic data of Holland and Powell (1998 updated in 2004). Mixing properties of phases used for the calculation were taken from Holland and Powell (1998): dolomite and epidote, Dale et al. (2000): amphibole, Holland and Powell (1996): clinopyroxene, Newton et al. (1980): plagioclase, White et al. (2000): garnet, Holland et al. (1998): chlorite.

\section{Petrography and mineral chemistry}

Calc-silicate rocks are usually present as $\mathrm{cm}$ to $\mathrm{m}$ thick layers rimming the contact between marble or skarn and metapelite. Sometimes they are enclosed in amphibolites, 
metapsammites or metapelites as $\mathrm{cm}$ to several tens of $\mathrm{m}$ thick bodies and/or up to $1 \mathrm{~m}$ thick nodules. All the samples exhibit similar mineralogy with variable amounts of the following minerals: Qtz $+\mathrm{Cpx}+\mathrm{Pl} \pm \mathrm{Kfs} \pm \mathrm{Czo}(\mathrm{Ep}) \pm$ $\mathrm{Grt} \pm \mathrm{Amp} \pm \mathrm{Cal} \pm \mathrm{Scp} \pm \mathrm{Ttn} \pm \mathrm{Chl} \pm \mathrm{Ap} \pm \mathrm{Aln}$ (Tab. 1). Two different groups of calc-silicate rocks are distinguished according to the presence or absence of garnet.

\subsection{Polička Unit}

Garnet-bearing calc-silicate rocks appear as up to $1 \mathrm{~m}$ thick nodules surrounded by gneisses in the central and southern parts of the PU (Buriánek 2005). However, in several $\mathrm{m}$ thick bodies of calc-silicate rocks located along the boundary with SU, garnet is present only in the southernmost part of the middle subunit. The primary metamorphic assemblage of the nodules consists of medium- to fine-grained subhedral clinopyroxene $(25-50$ vol. \%), plagioclase (25-45 vol. \%) and grossular-rich garnet (up to 10 vol. \%). Calcite is usually present only as small inclusions in pyroxene or epidote and occasionally forms anhedral grains rimmed by plagioclase $\left(\mathrm{An}_{94-97}\right)$. Anhedral quartz grains and subhedral to anhedral clinozoisite to $\mathrm{Fe}$-rich clinozoisite grains are often present (Fig. 2a). The content of the pistacite component $[\mathrm{Ps}=$ $\left.\mathrm{Fe}^{3+} /\left(\mathrm{Fe}^{3+}+\mathrm{Al}^{3+}\right)\right]$ is between 3 and 15 mol. \% (Tab. 2) and the individual samples exhibit weak chemical variations. Some grains are zoned, showing Fe-poor cores and Fe-rich rims. Clinopyroxene (Fig. 3a-b) composition is fairly uniform $\left[\mathrm{X}_{\mathrm{Fe}}=\mathrm{Fe}^{2+} /\left(\mathrm{Fe}^{2+}+\mathrm{Mg}\right)=0.33-0.49\right.$, Tab. 3]. Garnets form anhedral grains up to $1 \mathrm{~mm}$ in diameter. The core composition (Tab. 4) of individual grains is relatively homogeneous $\left(\mathrm{Grs}_{78-91} \mathrm{Alm}_{5-9} \mathrm{Sps}_{1-10}\right.$ $\left.\operatorname{Adr}_{1-3} \operatorname{Prp}_{0-1}\right)$. The garnet rims with significant almandine component $\left(\mathrm{Grs}_{48-91} \mathrm{Alm}_{8-34} \mathrm{Sps}_{5-8} \mathrm{Adr}_{1-4} \operatorname{Prp}_{0-3}\right)$ exhibit irregular patchy zoning (Fig. $4 a-b$ ). Garnets from younger quartz-plagioclase-garnet veins are richest in the almandine component $\left(\mathrm{Grs}_{42-51} \mathrm{Alm}_{33-39} \mathrm{Sps}_{8-10} \mathrm{Adr}_{4-6}\right.$ $\operatorname{Prp}_{3-5}$ ). Inclusions of clinozoisite, plagioclase and quartz are common close to the rim of the garnet grains. The chemical composition of inclusions in garnet identifies

$$
5 \mathrm{Cal}+3 \mathrm{Qtz}+2 \mathrm{Czo}=3 \mathrm{Grs}+\mathrm{H}_{2} \mathrm{O}+5 \mathrm{CO}_{2}
$$

Tab. 2 Representative chemical composition of epidotes, clinozoisites and scapolites

\begin{tabular}{|c|c|c|c|c|c|c|c|c|c|c|c|c|c|}
\hline \multicolumn{10}{|c|}{ Epidote group minerals } & \multicolumn{4}{|c|}{ Scapolite } \\
\hline Sample & $102 / 91$ & $163 / 95$ & $60 / 27$ & $151 / 5$ & $101 / 13$ & $138 / 34$ & Cach2 & KM4 & KM6 & Sample & $285 / 2$ & $60 / 8$ & KM2 \\
\hline $\mathrm{SiO}_{2}$ & 38.31 & 38.48 & 38.76 & 39.44 & 38.56 & 38.94 & 38.71 & 38.02 & 38.99 & $\mathrm{SiO}_{2}$ & 46.82 & 46.91 & 46.22 \\
\hline $\mathrm{TiO}_{2}$ & 0.04 & 0.18 & 0.04 & 0.09 & 0.21 & 0.06 & 0.00 & 0.19 & 0.39 & $\mathrm{TiO}_{2}$ & n.d. & n.d. & n.d. \\
\hline $\mathrm{Al}_{2} \mathrm{O}_{3}$ & 27.11 & 23.99 & 26.98 & 32.29 & 28.77 & 27.63 & 25.54 & 24.78 & 26.02 & $\mathrm{Al}_{2} \mathrm{O}_{3}$ & 26.46 & 26.60 & 35.55 \\
\hline $\mathrm{Cr}_{2} \mathrm{O}_{3}$ & 0.00 & 0.10 & 0.00 & 0.03 & 0.03 & 0.00 & 0.00 & 0.02 & 0.04 & $\mathrm{Cr}_{2} \mathrm{O}_{3}$ & n.d. & n.d. & n.d. \\
\hline $\mathrm{Fe}_{2} \mathrm{O}_{3}$ & 8.18 & 12.80 & 9.11 & 1.37 & 6.61 & 7.52 & 10.96 & 11.42 & 10.68 & $\mathrm{FeO}_{2}$ & 0.12 & 0.07 & 0.14 \\
\hline $\mathrm{MnO}$ & 0.04 & 0.18 & 0.07 & 0.02 & 0.06 & 0.12 & 0.26 & 0.07 & 0.16 & $\mathrm{MnO}$ & 0.04 & 0.00 & 0.01 \\
\hline $\mathrm{MgO}$ & 0.00 & 0.00 & 0.00 & 0.00 & 0.00 & 0.00 & 0.22 & 0.00 & 0.00 & $\mathrm{MgO}$ & 0.00 & 0.00 & 0.00 \\
\hline $\mathrm{CaO}$ & 23.93 & 23.48 & 23.86 & 24.65 & 24.21 & 23.92 & 23.42 & 23.57 & 23.55 & $\mathrm{CaO}$ & 17.33 & 17.65 & 18.56 \\
\hline $\mathrm{Na}_{2} \mathrm{O}$ & n.d. & n.d. & n.d. & n.d. & n.d. & n.d. & n.d. & n.d. & n.d. & $\mathrm{Na}_{2} \mathrm{O}$ & 3.77 & 3.40 & 1.35 \\
\hline $\mathrm{K}_{2} \mathrm{O}$ & n.d. & n.d. & n.d. & n.d. & n.d. & n.d. & n.d. & n.d. & n.d. & $\mathrm{K}_{2} \mathrm{O}$ & 0.05 & 0.18 & 0.02 \\
\hline $\mathrm{Cl}$ & n.d. & n.d. & n.d. & n.d. & n.d. & n.d. & n.d. & n.d. & n.d. & $\mathrm{Cl}$ & 0.01 & 0.14 & n.d. \\
\hline $\mathrm{SO}$ & n.d. & n.d. & n.d. & n.d. & n.d. & n.d. & n.d. & n.d. & n.d. & $\mathrm{SO}$ & 2.61 & 0.03 & n.d. \\
\hline TOTAL & 97.62 & 99.21 & 98.81 & 97.90 & 98.44 & 98.19 & 99.11 & 98.06 & 99.83 & TOTAL & 97.21 & 94.98 & 101.85 \\
\hline $\mathrm{Si}$ & 2.985 & 2.988 & 2.987 & 3.001 & 2.966 & 3.007 & 2.990 & 2.977 & 2.986 & $\mathrm{Si}$ & 7.203 & 7.193 & 6.295 \\
\hline $\mathrm{Ti}$ & 0.003 & 0.011 & 0.002 & 0.005 & 0.012 & 0.003 & 0.000 & 0.011 & 0.022 & $\mathrm{Ti}$ & n.d. & n.d. & n.d. \\
\hline $\mathrm{Al}$ & 2.489 & 2.196 & 2.450 & 2.895 & 2.608 & 2.514 & 2.325 & 2.287 & 2.348 & $\mathrm{Al}$ & 4.797 & 4.807 & 5.705 \\
\hline $\mathrm{Cr}$ & 0.000 & 0.006 & 0.000 & 0.002 & 0.002 & 0.000 & 0.000 & 0.001 & 0.002 & $\mathrm{Cr}$ & n.d. & n.d. & n.d. \\
\hline $\mathrm{Fe}^{3+}$ & 0.527 & 0.823 & 0.581 & 0.086 & 0.421 & 0.481 & 0.701 & 0.740 & 0.677 & $\mathrm{Fe}^{2+}$ & 0.015 & 0.009 & 0.016 \\
\hline $\mathrm{Mn}$ & 0.003 & 0.012 & 0.005 & 0.001 & 0.004 & 0.008 & 0.017 & 0.005 & 0.010 & $\mathrm{Mn}$ & 0.005 & 0.000 & 0.001 \\
\hline $\mathrm{Mg}$ & 0.000 & 0.000 & 0.000 & 0.001 & 0.000 & 0.000 & 0.025 & 0.000 & 0.000 & $\mathrm{Mg}$ & 0.000 & 0.000 & 0.000 \\
\hline $\mathrm{Ca}$ & 1.998 & 1.953 & 1.970 & 2.010 & 1.995 & 1.979 & 1.938 & 1.977 & 1.932 & $\mathrm{Ca}$ & 2.856 & 2.899 & 2.708 \\
\hline $\mathrm{Na}$ & n.d. & n.d. & n.d. & n.d. & n.d. & n.d. & n.d. & n.d. & n.d. & $\mathrm{Na}$ & 1.123 & 1.011 & 0.357 \\
\hline $\mathrm{K}$ & n.d. & n.d. & n.d. & n.d. & n.d. & n.d. & n.d. & n.d. & n.d. & K & 0.009 & 0.036 & 0.004 \\
\hline $\mathrm{Cl}$ & n.d. & n.d. & n.d. & n.d. & n.d. & n.d. & n.d. & n.d. & n.d. & $\mathrm{Cl}$ & 0.003 & 0.037 & 0.000 \\
\hline $\mathrm{S}$ & n.d. & n.d. & n.d. & n.d. & n.d. & n.d. & n.d. & n.d. & n.d. & $\mathrm{S}$ & 0.377 & 0.004 & 0.000 \\
\hline$\Sigma \mathrm{CAT}$. & 8.005 & 7.989 & 7.995 & 8.002 & 8.007 & 7.992 & 7.997 & 7.998 & 7.978 & $\Sigma \mathrm{CAT}$. & 16.389 & 15.995 & 15.087 \\
\hline Ps mol. \% & 18 & 27 & 19 & 3 & 14 & 16 & 23 & 24 & 22 & Me mol. \% & 72 & 74 & 88 \\
\hline
\end{tabular}


as the main clinozoisite breakdown reaction. Amphibole is typical retrograde mineral and its chemical composition ranges between actinolite and magnesiohornblende $\left(\mathrm{X}_{\mathrm{Fe}}\right.$ $=0.24-0.39, \mathrm{Si}=7.37-7.62 \mathrm{apfu})$. Titanite and apatite are always present as accessory phases.
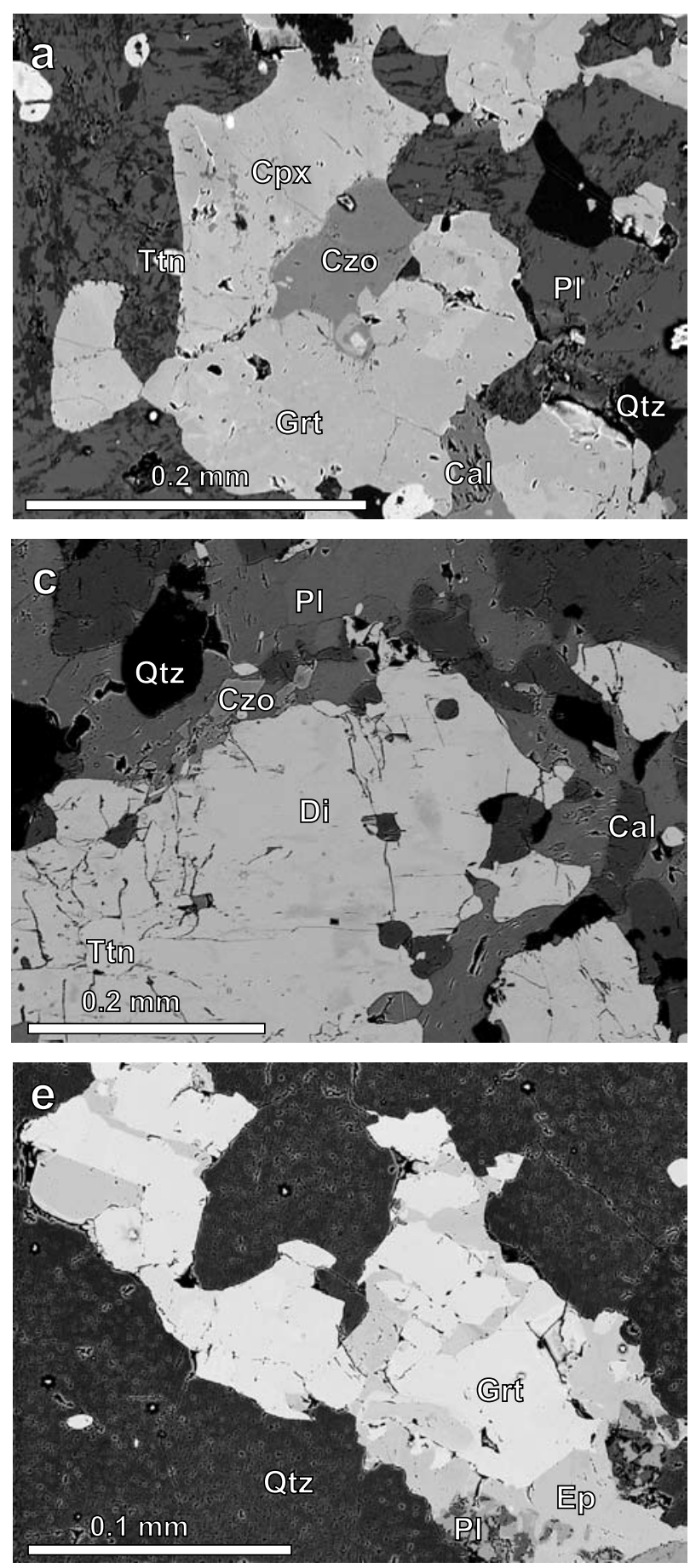

One calc-silicate rock from the lower subunit (sample 115) consists of millimetre- to centimetre-scale garnetrich and diopside-rich layers. Garnet-rich layers (Fig. 2b) consist of subhedral plagioclase $\left(\mathrm{An}_{62-65}\right)$, euhedral garnet, anhedral K-feldspar and quartz. Small $(0.1-0.5 \mathrm{~mm}$
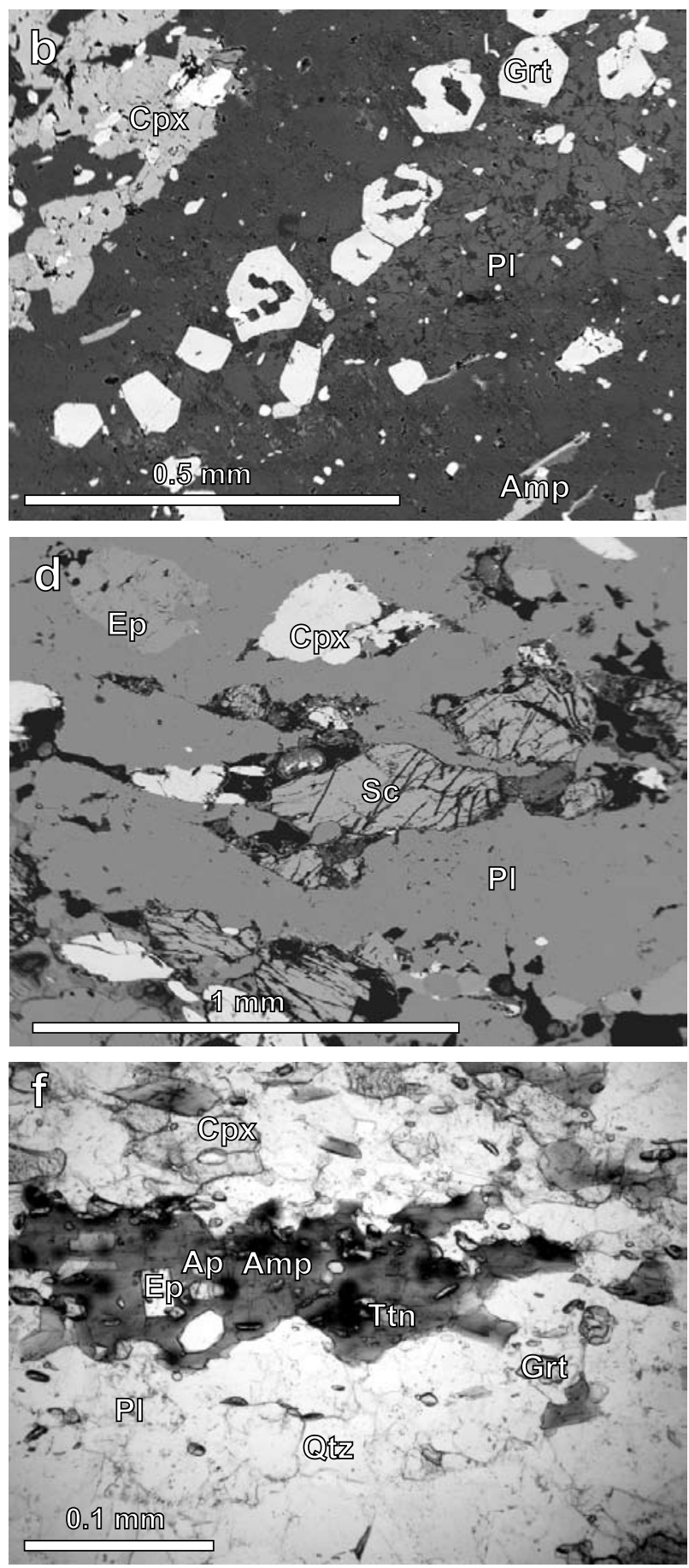

Fig. 2 Typical textures of calc-silicate rocks from the Svratka and Polička units (a to e = BSE images and $\mathrm{f}=$ plain polarized light): $\mathbf{a}-$ subhedral garnet partially replaced by clinozoisite and anorthite-rich plagioclase grains, which are, in turn, partially replaced by albite (Sádek, sample 144); b - relationships between garnet-rich and diopside-rich layers in calc-silicate rocks (Ubušín, sample 115); $\mathbf{c}$ - clinozoisite stable at the contact with calcite and quartz (Proseč, sample 138); d - calc-silicate rocks with scapolite, Nyklovice (sample 60); $\mathbf{e}$ - anhedral garnet rimmed by epidote (Kadov, sample KM6); $\mathbf{f}$ - subhedral amphibole porphyroblast with inclusions of pyroxene, titanite and epidote (Vepřová, sample KM3). 

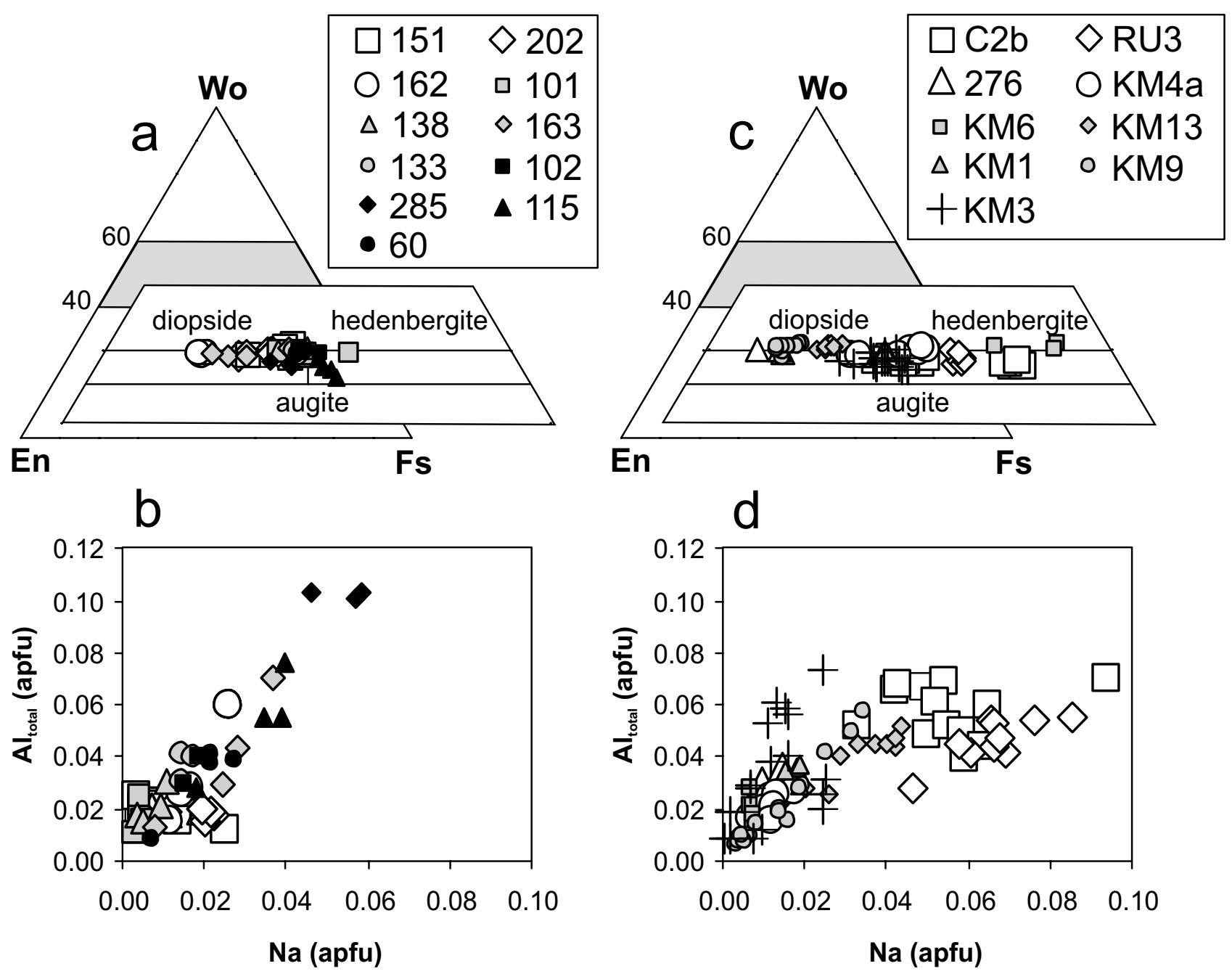

Fig. 3 Ternary plots En - Wo $+\mathrm{Fs}(\mathrm{a}, \mathrm{c})$ and binary plots $\mathrm{Na}-\mathrm{Al}_{\text {tot }}$ Moldanubian Zone and Svratka Unit (c-d).

(b, d) for the clinopyroxene compositions from the Polička Unit (a-b),

in diameter) euhedral, often atoll-shaped garnets have almandine-rich composition with significant amounts of pyrope, andradite and spessartine $\left(\mathrm{Alm}_{50-71} \mathrm{Grs}_{9-27}\right.$ $\mathrm{Sps}_{6-16} \operatorname{Prp}_{5-15} \mathrm{Adr}_{0-3}$ ). Diopside-rich layers exhibit similar mineral composition but, instead of garnet, they contain diopside and amphibole (ferroedenite to ferropargasie with $\mathrm{Fe} /(\mathrm{Fe}+\mathrm{Mg})=0.37-0.38$ and $\mathrm{Si}=6.39-6.53$ apfu). Several $\mathrm{mm}$ thick layers in clinopyroxene-bearing calc-silicate rocks (lower subunit, samples 285 and 60) containing almandine-rich garnet $\left(\mathrm{Grs}_{5-12} \mathrm{Alm}_{68-71} \mathrm{Sps}_{4-7}\right.$ $\operatorname{Prp}_{13-15} \mathrm{Adr}_{0-5}$ ) are rarely present.

Clinopyroxene-bearing calc-silicate rocks (Tab. 1) form small oval nodules up to $60 \mathrm{~cm}$ in diameter predominantly in the NW and NE parts of the middle subunit (sample 183), or several $\mathrm{m}$ thick elongated bodies located in the lower subunit, along the boundary with the adjacent SU (Buriánek 2006). Clinopyroxene and plagioclase $\left(\mathrm{An}_{32-95}\right)$ form subhedral grains or porphyroblasts (Fig. 2c). The samples with mineral assemblage
$\mathrm{Cpx}+\mathrm{Cal}+\mathrm{Pl}+\mathrm{Qtz}$ contain clinopyroxene with $\mathrm{X}_{\mathrm{Fe}}=$ $0.23-0.25$ and this value becomes higher $(0.34-0.59)$ in the samples with mineral assemblage $\mathrm{Cpx}+\mathrm{Pl}+\mathrm{Qtz}$ + Czo (Fig. 3a-b). The epidote group minerals (Fig. 5a) from calc-silicate rocks of the lower subunit have variable Ps contents (6 to $28 \mathrm{~mol}$. \%). The presence of relatively homogenous clinozoisite ( $\mathrm{Ps}=15-17 \mathrm{~mol} . \%)$ grains in contact with quartz and calcite indicates that the mineral assemblage in the nodules from the north-western part of the PU is stable below P-T-X conditions limited by reaction (1) and reactions

$$
\text { or } \quad \begin{aligned}
& 2 \mathrm{CzO}+\mathrm{CO}_{2}=\mathrm{Cal}+3 \mathrm{An}+\mathrm{H}_{2} \mathrm{O} \\
& 4 \mathrm{Czo}+\mathrm{Qtz}=\mathrm{Grs}+5 \mathrm{An}+2 \mathrm{H}_{2} \mathrm{O}
\end{aligned}
$$

No consistent chemical zoning pattern was observed in epidote group minerals of the calc silicate rocks from the middle subunit. Some subhedral grains are zoned with epidote cores ( $\mathrm{Ps}=24-28 \mathrm{~mol} . \%)$ and oscillatory-zoned clinozoisite rims ( $\mathrm{Ps}=6-19$ mol. \%), while others dis- 
Garnet-forming reactions in calc-silicate rocks

Tab. 3 Representative chemical composition of pyroxenes

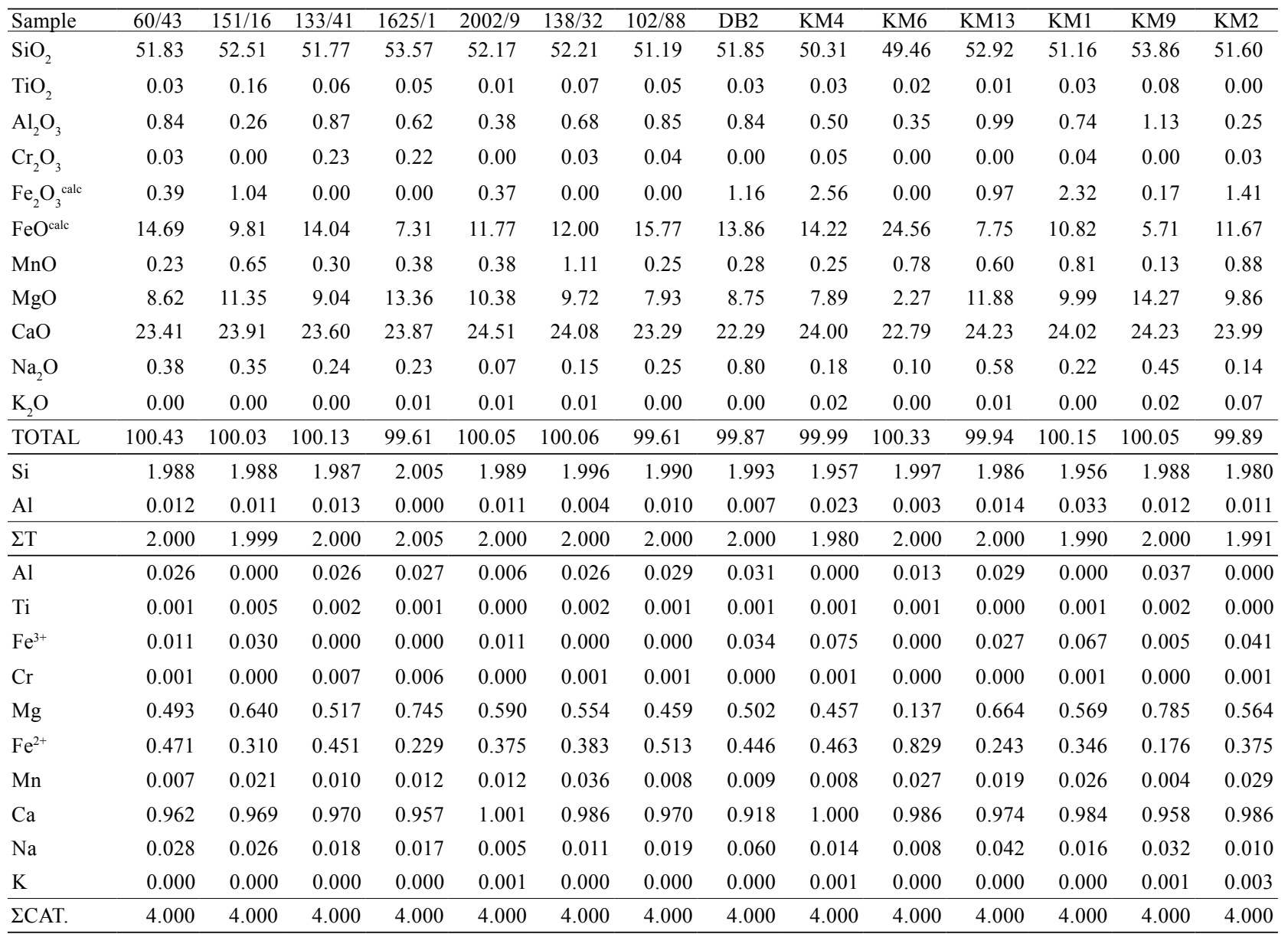

play the opposite zoning. The clinozoisite core $(\mathrm{Ps}=19$ mol. \%) is sometimes rimmed by symplectites composed of plagioclase $\left(\mathrm{An}_{51-57}\right)$ and Fe-rich clinozoisite (Ps = 20-21 mol. \%). Clinozoisite grains in the contact with calcite and/or plagioclase can be interpreted as result of reaction (2) reversal during retrogression. Weak zoning in $\mathrm{Fe}^{3+}$ is present in other grains situated inside the plagioclase crystals, probably representing a relict produced by prograde metamorphic reaction (2). The Mn content in all the studied epidote group minerals from the PU is usually below $0.01 \mathrm{apfu}$. Some samples contain amphibole (Tab. 5) grains with ferropargasite core $\left(\mathrm{X}_{\mathrm{Fe}}=0.38-0.49\right.$, $\mathrm{Si}=6.04-6.42 \mathrm{apfu})$ rimmed by actinolite or magnesiohornblende $\left(\mathrm{X}_{\mathrm{Fe}}=0.55-0.63, \mathrm{Si}=7.45-7.71 \mathrm{apfu}\right)$. On the other hand, amphiboles in samples from the southern part of the lower subunit exhibit reverse zoning with actinolite core $\left(\mathrm{X}_{\mathrm{Fe}}=0.50-0.51, \mathrm{Si}=7.50-7.51 \mathrm{apfu}\right)$ and hornblende $\operatorname{rim}\left(\mathrm{X}_{\mathrm{Fe}}=0.39-0.48, \mathrm{Si}=6.74-7.10\right.$ apfu). Subhedral scapolite is present in calc-silicate rocks associated with marbles or amphibolites (Fig. 2d). All analysed scapolites are meionite-rich (Me 71-74 wt. \%, EqAn 60-61\%), the $\mathrm{SO}_{3}$ content varies up to $2.60 \mathrm{wt}$. $\%$, and the $\mathrm{Cl}$ content is low, lower than 0.15 wt. $\%$. We suggest that scapolite was produced as a consequence of the clinozoisite breakdown:

$$
2 \mathrm{Czo}+\mathrm{CO}_{2}=\mathrm{Scp}+\mathrm{H}_{2} \mathrm{O}
$$

or of the plagioclase breakdown:

$$
3 \mathrm{An}+\mathrm{Cal}=\mathrm{Scp}
$$

(Newton and Goldsmith 1975; Buick and Cartwright 1994). Titanite and apatite are present as typical accessory phases.

\subsection{Svratka Unit}

Clinopyroxene-bearing and garnet-bearing calc-silicate rocks in the SU often occur as several $\mathrm{dm}$ to $\mathrm{m}$ thick layers within metapelites, skarns or marbles.

The early metamorphic assemblage of the garnetbearing calc-silicate rocks consists mainly of medium- to fine-grained subhedral diopside-rich (Fig. 3c-d) clinopyroxene (25-30 vol. \%), plagioclase (25-45 vol. \%) and garnet (30-40 vol. \%). Grossular-rich $\left(\mathrm{Grs}_{57-74} \mathrm{Alm}_{21-28}\right.$ $\mathrm{Sps}_{1-7} \operatorname{Prp}_{0-1} \mathrm{Adr}_{2-13}$ ) garnets form subhedral, sometimes poikilitic grains up to $0.5 \mathrm{~mm}$ in diameter. Garnets with significant zoning are relatively rare (Fig. 4b, c). Garnet grains have relatively homogeneous cores and usually 
Tab. 4 Representative chemical composition of garnets

\begin{tabular}{|c|c|c|c|c|c|c|c|c|c|c|c|c|c|c|}
\hline Sample & $151 / 13$ & $101 / 48$ & $2002 / 4$ & $115 / 56$ & $115 / 57$ & $60 / 20$ & $60 / 21$ & Cach2 & Cach2 & Cach2 & KM5 & KM13 & KM13 & KM3 \\
\hline $\mathrm{SiO}_{2}$ & 39.47 & 39.07 & 38.28 & 37.58 & 37.62 & 37.05 & 37.01 & 38.17 & 38.81 & 38.15 & 37.65 & 38.37 & 39.06 & 38.38 \\
\hline $\mathrm{TiO}_{2}$ & .09 & 0.17 & 0.40 & 0.10 & 0.17 & 0.00 & 0.02 & 0.27 & 0.07 & 0.26 & 0.20 & 0.39 & 0.04 & 0.11 \\
\hline $\mathrm{Al}_{2} \mathrm{O}_{3}$ & 21.13 & 20.66 & 20.79 & 20.80 & 20.57 & 20.65 & 20.44 & 14.97 & 19.50 & 15.80 & 18.83 & 19.21 & 21.17 & 21.01 \\
\hline $\mathrm{Cr}_{2} \mathrm{O}_{3}$ & 0.04 & 0.03 & 0.55 & 0.08 & 0.05 & 0.00 & 0.00 & 0.00 & 0.00 & 0.00 & 0.00 & 0.00 & 0.00 & 0.00 \\
\hline $\mathrm{e}_{2} \mathrm{O}_{3}$ & 0.46 & 1.26 & 1.38 & 0.48 & 0.85 & 1.25 & 1.11 & 7.38 & 2.52 & 6.66 & 2.97 & 3.69 & 1.79 & 0.74 \\
\hline $\mathrm{eO}$ & 9.18 & 9.54 & 16.03 & 22.94 & 22.97 & 31.39 & 31.26 & 10.41 & 13.46 & 11.58 & 19.26 & 2.85 & 0.27 & 20.97 \\
\hline $\mathrm{MnO}$ & 3.53 & 2.64 & 4.36 & 7.04 & 6.87 & 2.83 & 2.88 & 1.87 & 0.19 & 2.13 & 2.28 & 1.42 & 0.20 & 5.10 \\
\hline $\mathrm{MgO}$ & 0.29 & 0.16 & 0.74 & 1.24 & 1.27 & 3.29 & 3.53 & 0.08 & 0.03 & 0.08 & 0.19 & 0.00 & 0.00 & 1.20 \\
\hline $\mathrm{Na}_{2} \mathrm{O}$ & 0.00 & 0.01 & 0.18 & 0.03 & 0.05 & 0.36 & 0.43 & 0.01 & 0.00 & 0.00 & 0.02 & 0.00 & 0.01 & 0.02 \\
\hline $\mathrm{CaO}$ & 25.76 & 26.57 & 19.45 & 9.94 & 10.13 & 3.69 & 2.97 & 26.68 & 25.60 & 25.67 & 18.54 & 33.74 & 36.93 & 13.80 \\
\hline Total & 99.98 & 100.10 & 102.18 & 100.23 & 100.56 & 100.50 & 99.65 & 99.84 & 100.18 & 100.33 & 99.94 & 99.67 & 99.47 & 101.33 \\
\hline $\mathrm{Si}$ & 3.041 & 3.019 & 2.955 & 2.998 & 2.995 & 2.963 & 2.979 & 3.043 & 3.025 & 3.027 & 3.003 & 2.967 & 2.974 & 3.003 \\
\hline $\mathrm{Ti}$ & 0.000 & 0.000 & 0.023 & 0.002 & 0.005 & 0.000 & 0.001 & 0.000 & 0.000 & 0.000 & 0.000 & 0.023 & 0.002 & 0.000 \\
\hline$\Sigma \mathrm{T}$ & 3.042 & 3.019 & 2.978 & 3.000 & 3.000 & 2.963 & 2.980 & 3.043 & 3.025 & 3.027 & 3.003 & 2.990 & 2.976 & 3.003 \\
\hline $\mathrm{Al}$ & 1.919 & 1.882 & 1.891 & 1.956 & 1.930 & 1.946 & 1.939 & 1.406 & 1.792 & 1.477 & 1.770 & 1.751 & 1.900 & 1.937 \\
\hline $\mathrm{Cr}$ & 0.002 & 0.002 & 0.034 & 0.005 & 0.003 & 0.000 & 0.000 & 0.000 & 0.000 & 0.000 & 0.000 & 0.000 & 0.000 & 0.000 \\
\hline $\mathrm{Fe}^{3+}$ & 0.027 & 0.073 & 0.080 & 0.029 & 0.051 & 0.075 & 0.067 & 0.443 & 0.148 & 0.397 & 0.178 & 0.215 & 0.103 & 0.044 \\
\hline $\mathrm{Ti}$ & 0.005 & 0.010 & 0.000 & 0.004 & 0.005 & 0.000 & 0.000 & 0.016 & 0.004 & 0.015 & 0.012 & 0.000 & 0.000 & 0.007 \\
\hline$\Sigma \mathrm{B}$ & 1.953 & 1.966 & 2.005 & 1.994 & 1.989 & 2.021 & 2.006 & 1.865 & 1.944 & 1.890 & 1.960 & 1.966 & 2.002 & 1.988 \\
\hline $\mathrm{Fe}^{2+}$ & 0.591 & 0.617 & 1.035 & 1.530 & 1.529 & 2.099 & 2.104 & 0.694 & 0.877 & 0.769 & 1.284 & 0.184 & 0.017 & 1.372 \\
\hline $\mathrm{Mn}$ & 0.231 & 0.173 & 0.285 & 0.476 & 0.464 & 0.192 & 0.196 & 0.126 & 0.012 & 0.143 & 0.154 & 0.093 & 0.013 & 0.338 \\
\hline $\mathrm{Mg}$ & 0.034 & 0.018 & 0.085 & 0.148 & 0.151 & 0.392 & 0.424 & 0.009 & 0.003 & 0.009 & 0.022 & 0.000 & 0.000 & 0.139 \\
\hline $\mathrm{Ca}$ & 2.127 & 2.200 & 1.609 & 0.850 & 0.864 & 0.316 & 0.256 & 2.278 & 2.138 & 2.182 & 1.585 & 2.795 & 3.013 & 1.157 \\
\hline $\mathrm{Na}$ & 0.000 & 0.003 & 0.042 & 0.007 & 0.011 & 0.085 & 0.103 & 0.002 & 0.000 & 0.000 & 0.006 & 0.000 & 0.002 & 0.005 \\
\hline$\Sigma$ A & 2.982 & 3.010 & 3.057 & 3.011 & 3.019 & 3.085 & 3.082 & 3.110 & 3.032 & 3.103 & 3.051 & 3.072 & 3.045 & 3.011 \\
\hline$\overline{\Sigma C A T .}$ & 7.978 & 7.995 & 8.040 & 8.005 & 8.008 & 8.069 & 8.068 & 8.017 & 7.999 & 8.019 & 8.014 & 8.028 & 8.024 & 8.002 \\
\hline
\end{tabular}

show several $\mu \mathrm{m}$ thick irregular rims rich in Adr and/ or Grs component. The Grs-rich rim is often partially replaced by younger epidote (Fig. 2e). Almandine-grossular garnet in the core is in equilibrium with Na-rich hedenbergite $\left(\mathrm{X}_{\mathrm{Fe}}=0.62-0.73, \mathrm{Na}_{2} \mathrm{O}=0.42-0.47\right.$ wt. \%). Andradite- and grossular-rich rims $\left(\mathrm{Grs}_{48-59} \mathrm{Alm}_{29-47} \mathrm{Sps}_{3-5}\right.$ $\left.\operatorname{Prp}_{1} \mathrm{Adr}_{8-11}\right)$ are in equilibrium with Na-poor clinopyroxene $\left(\mathrm{Na}_{2} \mathrm{O}<0.15\right.$ wt. \%) in the matrix (Tab. 3). Some garnet rims also preserve early clinozoisite $(\mathrm{Ps}=13-14$ mol. \%) and quartz inclusions as the relicts after reactions (1) or (3). Minerals of the epidote group are minor constituents (up to 5 vol. \%; Fig. 5b). Subhedral younger epidote ( $\mathrm{Ps}=19-22 \mathrm{~mol} . \%$ ), together with quartz and plagioclase, sometimes partially replaced garnet. The replacement textures can by explained by reaction (3) reversal. Garnet is rarely rimmed by fine-grained aggregate of plagioclase, quartz and calcite, which can be explained by a model reaction:

$$
\mathrm{Grs}+2 \mathrm{CO}_{2}=\mathrm{An}+2 \mathrm{Cal}+\mathrm{Qtz}
$$

In the same sample, calcite forms intergrowths with plagioclase $\left(\mathrm{An}_{90-93}\right)$ around epidote suggesting its breakdown via reaction (2) reversal. Anhedral quartz grains are often present. Anhedral to subhedral amphiboles (Fig. 5d, f) range in composition from actinolite to hornblende, ferroedenite and hastingsite $\left(\mathrm{X}_{\mathrm{Fe}}=0.18-0.62\right.$, $\mathrm{Si}=6.16-7.89$ apfu, $\mathrm{K}+\mathrm{Na}=0.02-0.75 \mathrm{apfu}$; Tab. 5). Titanite and apatite are always present as accessory phases. K-feldspar occurs in some of the samples, often interstitially between plagioclase grains or in veins that cut across the plagioclase.

Clinopyroxene-bearing calc-silicate rocks are more abundant. Clinopyroxene is present in subhedral grains, porphyroblasts or poikiloblasts and only rarely forms almost monomineral bands. Calc-silicates associated with skarns contain clinopyroxene with higher $\mathrm{X}_{\mathrm{Fe}}$ than the rocks associated with marbles and gneisses (0.31-0.87 vs. $0.11-0.31$; Tab. 3). Clinopyroxene grains are locally rimmed by needles of younger actinolite $\left(\mathrm{X}_{\mathrm{Fe}}=0.59\right.$ $0.61, \mathrm{Ca}+\mathrm{Na}=1.8-1.9)$. Subhedral to anhedral plagioclase and quartz are occasionally present. Calcite was usually found as inclusions in clinozoisite being never in contact with plagioclase. Minerals of the epidote group (Tab. 2) appear as porphyroblasts, or as small subhedral grains in the matrix ( $\mathrm{Ps}=2-14$ mol. \%). The presence 

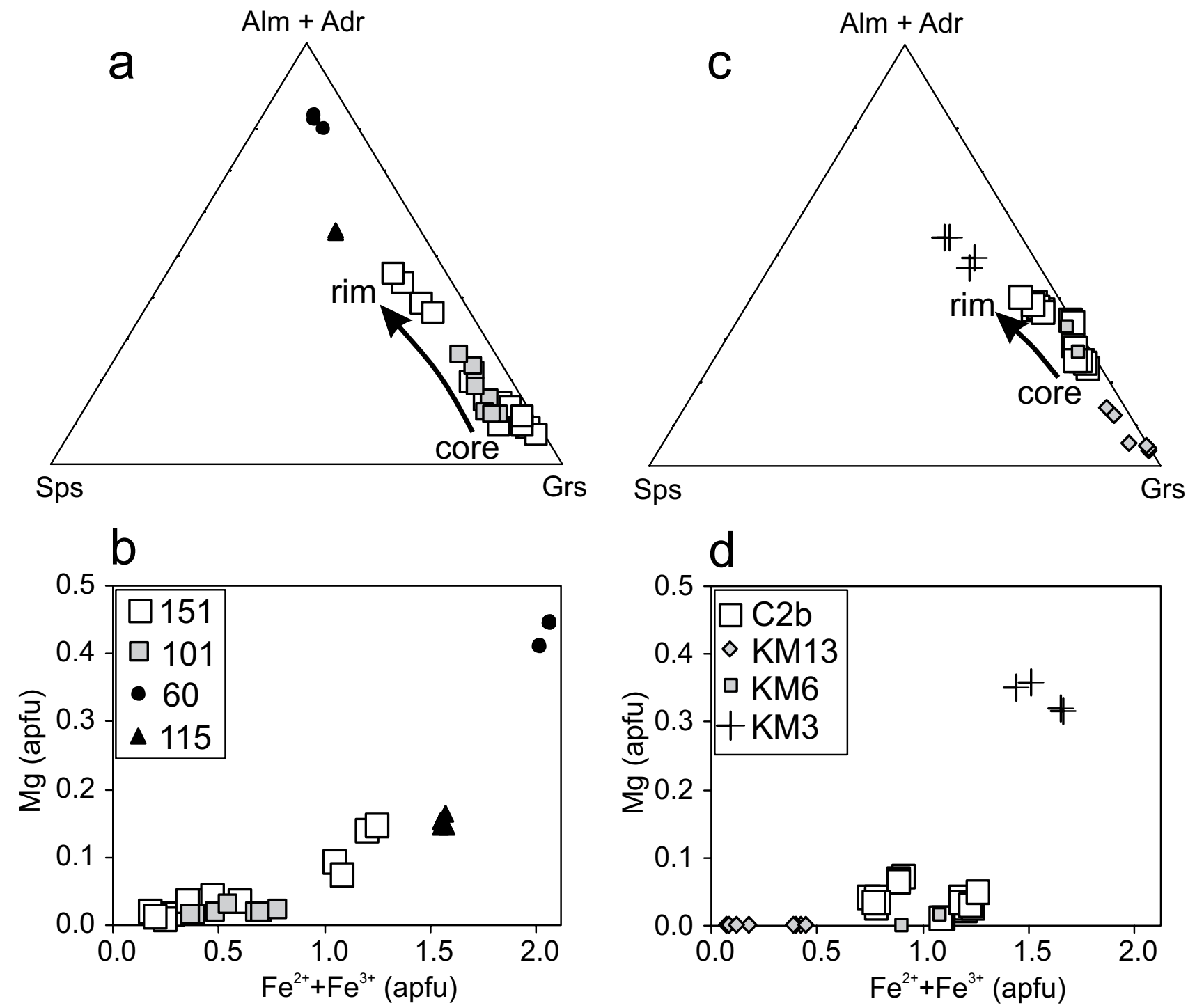

Fig. 4 Ternary Sps - Alm + Adr - Grs (a, c) and binary $\mathrm{Fe}^{2+}+\mathrm{Fe}^{3+}-\mathrm{Mg}(\mathrm{b}, \mathrm{d})$ plots for the garnet composition in the Polička Unit (a-b), Moldanubian Zone and Svratka Unit (c-d).

of plagioclase and calcite relicts enclosed in clinozoisite porphyroblasts indicates the reversal of the model reaction (2). Euhedral K-feldspar, scapolite or elongated subhedral amphibole are sometimes present. Formation of tremolite needles partially replacing diopside can be explained by the model reaction:

$$
5 \mathrm{Di}+\mathrm{H}_{2} \mathrm{O}+3 \mathrm{CO}_{2}=2 \mathrm{Qtz}+\mathrm{Tr}+3 \mathrm{Cal}
$$

Titanite and apatite are present as typical accessory phases.

\subsection{Moldanubian Zone}

The calc-silicate rocks in the $\mathrm{MZ}$ form $\mathrm{dm}$ to $\mathrm{m}$ thick layers between metapelites and skarns or marbles.

The garnet-bearing calc-silicate samples contain amphibole, plagioclase, clinopyroxene and titanite (Fig. 2f) with occasional garnet, K-feldspar, biotite and scapolite. Subhedral plagioclase $\left(\mathrm{An}_{20-23}\right)$ is sericitized and partially replaced by younger albite. Interstitial grains of K-feldspar $\left(\mathrm{Ab}_{7-9}\right)$ and columnar scapolite are rare. Scapolite (Tab. 2) represents a marialite-meionite binary solid solution (Me 88-94 wt. \%, EqAn 91-97 \%). Garnets form either anhedral to subhedral isolated grains or massive bands with abundant inclusions of clinopyroxene and plagioclase. Garnet grains up to $2 \mathrm{~mm}$ in diameter are relatively homogenous $\left(\mathrm{Grs}_{29-37} \mathrm{Alm}_{42-50} \mathrm{Sps}_{11-15} \operatorname{Prp}_{4-5}\right.$ $\mathrm{Adr}_{1-3}$ ). The garnet composition (mainly almandine and spessartine component in the garnet, Tab. 4) indicates some garnet forming reaction other than (1) (Donohue and Essene 2000), for example:

$$
12 \mathrm{Ep}=\mathrm{Grs}+4 \mathrm{Alm}+6 \mathrm{H}_{2} \mathrm{O}+3 \mathrm{O}_{2}
$$

The presence of the spessartine component in garnet enables to write a reaction analogous to 8 involving 

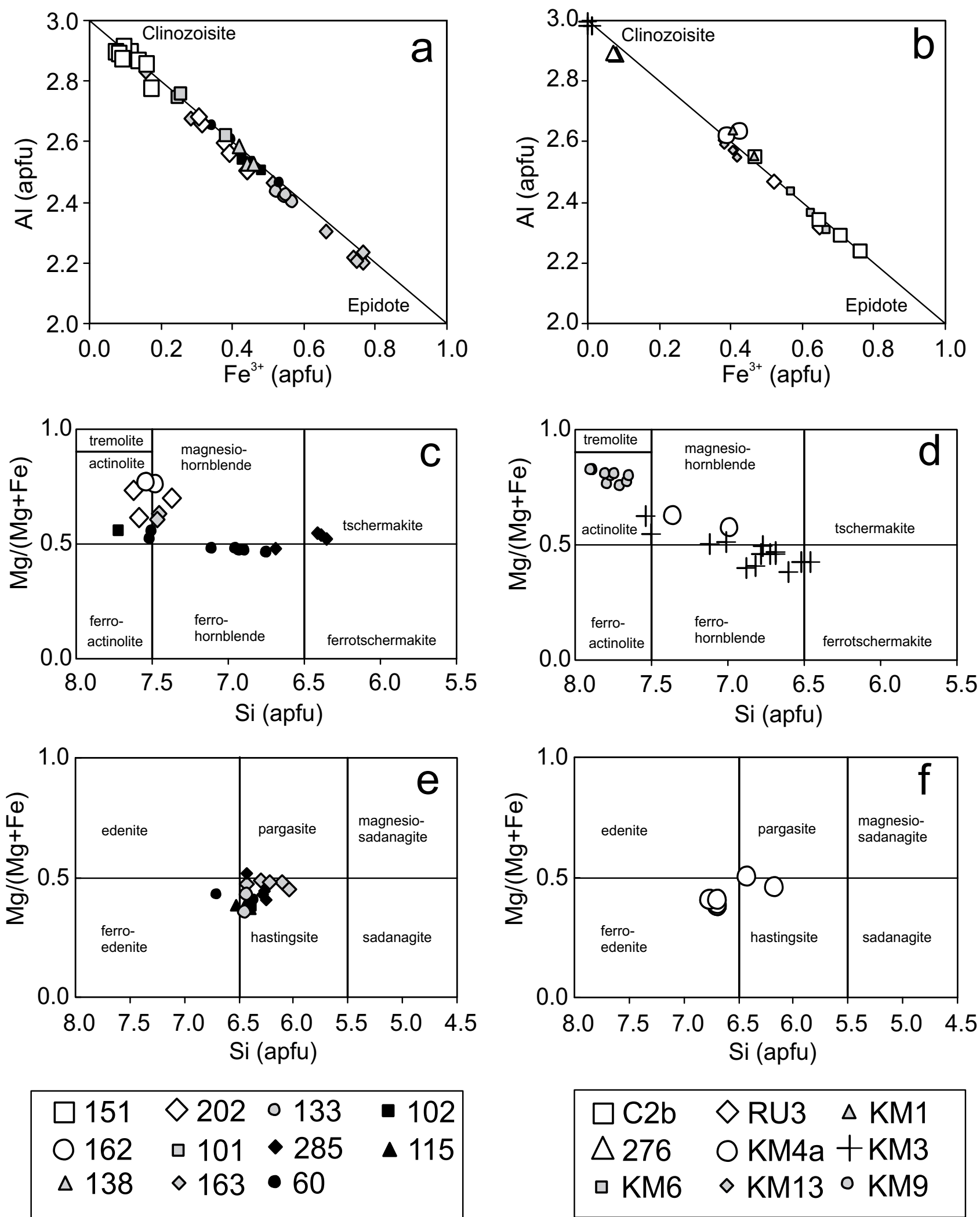

$\square \mathrm{C} 2 \mathrm{~b} \diamond \mathrm{RU} 3 \quad \Delta \mathrm{KM} 1$ $\triangle 276 \quad \mathrm{KM} 4 \mathrm{a}+\mathrm{KM} 3$ 口 KM6 $\diamond \mathrm{KM} 13 \circ \mathrm{KM} 9$

Fig. 5 Binary diagrams Al-Fe ${ }^{3+}$ for epidote group minerals (a-b) and classification diagrams (Leake et al. 1997) for amphiboles (c-f), from the Polička Unit (a, c, e), Moldanubian Zone and Svratka Unit (b, d, f). 
Garnet-forming reactions in calc-silicate rocks

Tab. 5 Representative chemical composition of amphiboles

\begin{tabular}{|c|c|c|c|c|c|c|c|c|c|c|c|c|c|c|}
\hline Numb & $15 / 63$ & $102 / 80$ & $121 / 19$ & $60 / 33$ & $60 / 13$ & $163 / 119$ & $133 / 44$ & $132 / 30$ & $1625 / 2$ & $2002 / 2$ & KM4 & KM9 & KM3 & KM3 \\
\hline $\mathrm{iO}_{2}$ & 82 & 93 & 5796 & 4632 & .27 & 2 & 27 & 46.80 & 09 & 1 & 0.20 & 5.45 & 7.12 & 45.74 \\
\hline $\mathrm{TiO}_{2}$ & 1.06 & 0.07 & 0.01 & 0.37 & 0.38 & 011 & 0.74 & 0.61 & 0.37 & 0.08 & 1.66 & 009 & 0.74 & 0.94 \\
\hline $\mathrm{Al}_{2} \mathrm{O}_{3}$ & 11.05 & 2.61 & 1.15 & 9.35 & 11.05 & 4.51 & 12.91 & 11.34 & 4.80 & 3.83 & 12.36 & 2.27 & 06 & 9.36 \\
\hline $\mathrm{Cr}_{2} \mathrm{O}_{3}$ & 0.08 & 0.04 & 0.01 & 0.06 & 0.09 & 0.00 & 0.02 & 0.04 & 0.23 & 0.06 & 0.08 & 0.00 & 0.10 & 0.02 \\
\hline $\mathrm{e}_{2} \mathrm{O}_{3}^{\text {calc }}$ & .04 & 00 & 0.00 & 0.35 & 0.11 & 070 & 0.51 & 3.54 & 0.66 & 1.15 & 2.79 & 0.00 & 2.03 & 1.41 \\
\hline$e^{\text {calc }}$ & 19.39 & 17.27 & 2.56 & 18.71 & 19.04 & 15.08 & 18.37 & 11.32 & 8.98 & 14.56 & 17.26 & 7.98 & 16.57 & 19.98 \\
\hline $\mathrm{InO}$ & 0.89 & 0.19 & 0.12 & 0.19 & 0.22 & 0.33 & 0.20 & 0.29 & 0.32 & 0.29 & 0.25 & 0.08 & 0.89 & 0.63 \\
\hline $\mathrm{MgO}$ & 6.77 & 11.95 & 22.15 & 8.87 & 8.10 & 12.76 & 7.75 & 11.05 & 16.15 & 12.93 & 8.11 & 18.37 & 9.64 & 7.34 \\
\hline $\mathrm{CaO}$ & 11.86 & 12.57 & 13.61 & 12.12 & 12.22 & 12.62 & 12.23 & 11.71 & 12.52 & 12.69 & 11.96 & 13.21 & 11.95 & 11.89 \\
\hline $\mathrm{Na}_{2} \mathrm{O}$ & 1.13 & 0.29 & 0.19 & 0.92 & 1.01 & 0.47 & 1.01 & 0.78 & 0.42 & 0.22 & 1.42 & 0.24 & 0.66 & 0.71 \\
\hline $\mathrm{K}_{2} \mathrm{O}$ & 1.40 & 0.19 & 0.11 & 0.98 & 1.30 & 0.42 & 1.62 & 0.39 & 0.13 & 0.03 & 1.75 & 0.13 & 0.46 & 0.52 \\
\hline $\mathrm{H}_{2} \mathrm{O}$ & 1.70 & 2.03 & 2.20 & 2.02 & 2.00 & 2.00 & ונו & 2.08 & 2.10 & 2.07 & 1.97 & 2.15 & 2.03 & 2.01 \\
\hline COTAI & 0.46 & 99.15 & 100.06 & 100.24 & 99.79 & 99.98 & 99.62 & 99.96 & 99.81 & 99.93 & 99.80 & 99.96 & 00.25 & 100.55 \\
\hline $\mathrm{Si}$ & 6.526 & 7.714 & 7.965 & 6.932 & 6.700 & 7.463 & 6.426 & 6.798 & 7.537 & 7.581 & 6.164 & 7.801 & 7.004 & 6.876 \\
\hline $\mathrm{Al}^{\mathrm{IV}}$ & 1.474 & 0.286 & 0.035 & 1.068 & 1.300 & 0.537 & 1.574 & 1.202 & 0.463 & 0.419 & 1.836 & 0.199 & 0.996 & 1.124 \\
\hline$\Sigma T$ & 8.000 & 8.000 & 8.000 & 8.000 & 8.000 & 8.000 & 8.000 & 8.000 & 8.000 & 8.000 & 8.000 & 8.000 & 8.000 & 8.000 \\
\hline $\mathrm{Al}^{\mathrm{VI}}$ & 0.511 & 0.171 & 0.151 & 0.580 & 0.672 & 0.242 & 0.740 & 0.738 & 0.340 & 0.240 & 0.397 & 0.177 & 0.416 & 0.535 \\
\hline$\Gamma \mathrm{i}$ & 0.121 & 0.008 & 0.001 & 0.041 & 0.043 & 0.012 & 0.085 & 0.067 & 0.039 & 0.008 & 0.191 & 0.009 & 0.083 & 0.106 \\
\hline $\mathrm{Fe}^{3+}$ & 0.234 & 0.000 & 0.000 & 0.040 & 0.013 & 0.078 & 0.058 & 0.387 & 0.071 & 0.126 & 0.321 & 0.000 & 0.227 & 0.159 \\
\hline 1 & 09 & 5 & 1 & & .011 & 0 & 0.003 & 05 & 0.026 & 0.007 & 0.009 & 0.000 & 0.011 & 0.002 \\
\hline $\mathrm{Mg}$ & 1 & 2 & 9 & 9 & 27 & 8 & 56 & 93 & 3.418 & 9 & 1.8 & 3.852 & 2.136 & 1.646 \\
\hline $\mathrm{Fe}^{2+}$ & 2.472 & 2.146 & 0.294 & 2.342 & 2.410 & 1.848 & 2.336 & 1.375 & 1.066 & 1.775 & 2.212 & 0.939 & 2.059 & 2.512 \\
\hline $\mathrm{Mn}$ & 0.115 & 0.024 & 0.014 & 0.013 & 0.024 & 0.032 & 0.022 & 0.035 & 0.039 & 0.036 & 0.016 & 0.010 & 0.066 & 0.041 \\
\hline$\Sigma \mathrm{C}$ & 5.000 & 5.000 & 5.000 & 5.000 & 5.000 & 5.000 & 5.000 & 5.000 & 5.000 & 5.000 & 5.000 & 4.988 & 5.000 & 5.000 \\
\hline $\mathrm{Mn}$ & 0.000 & 0.000 & 0.000 & 0.011 & 0.004 & 0.008 & 0.004 & 0.000 & 0.000 & 0.000 & 0.016 & 0.000 & 0.045 & 0.039 \\
\hline $\mathrm{Ca}$ & 1.937 & 2.001 & 2.004 & 1.942 & 1.982 & 1.982 & 1.991 & 1.823 & 1.904 & 1.981 & 1.965 & 1.991 & 1.903 & 1.916 \\
\hline $\mathrm{Na}$ & 0.063 & 0.000 & 0.000 & 0.047 & 0.014 & 0.010 & 0.005 & 0.177 & 0.096 & 0.019 & 0.019 & 0.009 & 0.052 & 0.045 \\
\hline$\Sigma \mathrm{B}$ & 2.000 & 2.001 & 2.004 & 2.000 & 2.000 & 2.000 & 2.000 & 2.000 & 2.000 & 2.000 & 2.000 & 2.000 & 2.000 & 2.000 \\
\hline $\mathrm{Na}$ & 0.270 & 0.084 & 0.050 & 0.220 & 0.281 & 0.124 & 0.292 & 0.043 & 0.019 & 0.043 & 0.404 & 0.057 & 0.139 & 0.161 \\
\hline $\mathrm{K}$ & 0.271 & 0.037 & 0.018 & 0.187 & 0.251 & 0.079 & 0.315 & 0.072 & 0.024 & 0.006 & 0.342 & 0.023 & 0.087 & 0.100 \\
\hline$\Sigma \mathrm{A}$ & 0.541 & 0.121 & 0.068 & 0.407 & 0.532 & 0.203 & 0.607 & 0.116 & 0.043 & 0.049 & 0.746 & 0.080 & 0.227 & 0.260 \\
\hline SCAT. & 15.541 & 15.121 & 15.072 & 15.407 & 15.532 & 15.203 & 15.607 & 15.116 & 15.043 & 15.049 & 15.746 & 15.068 & 15.227 & 15.260 \\
\hline
\end{tabular}

( $\mathrm{Cl}, \mathrm{F}$ below detection)

Mn released from the piemontite component in epidote (Pm)

$$
12 \mathrm{Pm}=8 \mathrm{Grs}+4 \mathrm{Sps}+6 \mathrm{H}_{2} \mathrm{O}+3 \mathrm{O}_{2}
$$

Clinopyroxene $\left(\mathrm{X}_{\mathrm{Fe}}=0.30-0.45\right.$, Figs $\left.3 \mathrm{~b}, \mathrm{~d}\right)$ forms subhedral grains, and is locally replaced with, or surrounded by, up to $3 \mathrm{~mm}$ long magnesio- and ferrohornblende porphyroblasts with abundant inclusions of titanite, scapolite and quartz. Titanite, apatite and zircon are common accessory phases in a majority of the calcsilicate rocks in the MZ.

Clinopyroxene-bearing calc-silicate rocks are mediumgrained with granoblastic texture, often layered. Individual layers are several $\mathrm{cm}$ thick and differ in proportions of calcite, clinopyroxene and feldspars. Clinopyroxene (Tab. 3) occurs as crystals up to $2 \mathrm{~mm}$ in diameter in calc-silicate rocks adjacent to marble $\left(\mathrm{X}_{\mathrm{Fe}}=0.16-0.22\right)$ or migmatite $\left(\mathrm{X}_{\mathrm{Fe}}=0.38-0.41\right)$. Amphibole (Tab. 5) composition in the sample associated with marbles is remarkably homogeneous $\left(\mathrm{X}_{\mathrm{Fe}}=0.75-0.82, \mathrm{Si}=7.6-7.9 \mathrm{apfu}\right)$. Plagioclase $\left(\mathrm{An}_{21-24}\right)$ is usually the dominant mineral (65-80 vol. \%) and the content of clinopyroxene is 20-35 vol. \%. Quartz, K-feldspar $\left(\mathrm{Ab}_{8-9}\right)$ and biotite are minor mineral phases. Younger epidote grains and/or needles of actinolitic amphibole are locally abundant.

\section{Whole-rock chemistry}

Geochemical data indicate a close relationship of samples from the MZ, SU and PU (Tab. 6). We can also see weak 
Tab. 6 Representative whole-rock chemical analyses

\begin{tabular}{|c|c|c|c|c|c|c|c|c|c|c|}
\hline Sample & KM2 & KM3 & KM4a & KM1 & KM9 & KM6 & $\mathrm{C} 2$ & $\mathrm{C} 2$ & 101 & 60 \\
\hline $\mathrm{SiO}_{2}$ & 68.84 & 47.34 & 61.58 & 64.04 & 54.90 & 65.77 & 58.30 & 67.73 & 54.30 & 72.56 \\
\hline $\mathrm{TiO}_{2}$ & 0.43 & 0.51 & 0.52 & 0.39 & 0.60 & 0.55 & 0.61 & 0.64 & 0.40 & 0.39 \\
\hline $\mathrm{Al}_{2} \mathrm{O}_{3}$ & 11.07 & 15.54 & 11.08 & 12.75 & 16.19 & 11.76 & 13.89 & 12.59 & 16.06 & 11.56 \\
\hline $\mathrm{Fe}_{2} \mathrm{O}_{3}$ & 0.47 & 2.41 & 0.31 & 0.65 & 0.25 & 1.72 & 2.04 & 0.89 & 4.79 & 2.95 \\
\hline $\mathrm{FeO}$ & 2.62 & 9.47 & 2.93 & 3.18 & 1.79 & 4.63 & 5.12 & 2.72 & n. d. & n. d. \\
\hline $\mathrm{MgO}$ & 2.23 & 1.58 & 1.66 & 2.55 & 4.58 & 1.55 & 2.29 & 1.68 & 1.44 & 1.20 \\
\hline $\mathrm{MnO}$ & 0.18 & 0.18 & 0.05 & 0.26 & 0.08 & 0.29 & 0.24 & 0.12 & 0.46 & 0.06 \\
\hline $\mathrm{CaO}$ & 7.16 & 18.63 & 13.08 & 12.35 & 11.05 & 9.74 & 10.77 & 6.93 & 18.52 & 5.21 \\
\hline $\mathrm{Na}_{2} \mathrm{O}$ & 2.86 & 1.13 & 1.64 & 2.41 & 2.46 & 1.66 & 5.10 & 4.84 & 0.37 & 2.07 \\
\hline $\mathrm{K}_{2} \mathrm{O}$ & 3.12 & 0.43 & 2.02 & 0.24 & 5.17 & 0.59 & 1.03 & 1.10 & 0.16 & 2.59 \\
\hline $\mathrm{P}_{2} \mathrm{O}_{5}$ & 0.14 & 0.17 & 0.13 & 0.12 & 0.25 & 0.14 & 0.17 & 0.16 & 0.35 & 0.16 \\
\hline LOI & 0.75 & 1.83 & 4.82 & 0.82 & 1.8 & 1.53 & 0.44 & 0.58 & 2.95 & 1.24 \\
\hline Total & 99.87 & 99.22 & 99.82 & 99.76 & 99.12 & 99.93 & 100 & 99.98 & 99.8 & 99.99 \\
\hline $\mathrm{Nb}$ & 9.0 & 9.0 & 10.0 & 11.0 & 15.0 & 9.0 & 13.3 & 11.9 & 12.8 & 7.0 \\
\hline $\mathrm{Rb}$ & 113.0 & 30.0 & 86.0 & 23.0 & 171.0 & 36.0 & 62.9 & 44.0 & 5.8 & 82.0 \\
\hline $\mathrm{Sn}$ & 4 & 298 & 7 & 3 & 43 & 22 & 70 & 18 & 10 & 2 \\
\hline $\mathrm{Sr}$ & n. d. & n. d. & n. d. & n. d. & n. d. & n. d. & 677.6 & 654.7 & 245.1 & 598.7 \\
\hline $\mathrm{U}$ & 2.0 & $<0.1$ & 5.0 & 4.0 & 2.0 & $<0.1$ & 4.3 & 3.5 & 1.7 & 1.9 \\
\hline $\mathrm{Zr}$ & 157.0 & 132.0 & 143.0 & 85.0 & 276.0 & 155.0 & 164.7 & 246.4 & 118.8 & 196.6 \\
\hline $\mathrm{Y}$ & 25.0 & 29.0 & 27.0 & 22.0 & 44.7 & 24.0 & 28.2 & 27.5 & 23.8 & 16.4 \\
\hline $\mathrm{La}$ & n. d. & n. d. & n. d. & n. d. & 54.5 & n. d. & 33.8 & 34.6 & 18.5 & 15.7 \\
\hline $\mathrm{Ce}$ & n. d. & n. d. & n. d. & n. d. & 115.9 & n. d. & 68.1 & 65.5 & 41.7 & 45.0 \\
\hline $\operatorname{Pr}$ & n. d. & n. d. & n. d. & n. d. & 12.61 & n. d. & 7.94 & 8.19 & 4.18 & 3.73 \\
\hline $\mathrm{Nd}$ & n. d. & n. d. & n. d. & n. d. & 49.54 & n. d. & 32.90 & 33.20 & 19.60 & 15.50 \\
\hline $\mathrm{Sm}$ & n. d. & n. d. & n. d. & n. d. & 12.5 & n. d. & 5.8 & 6.0 & 3.9 & 3.2 \\
\hline $\mathrm{Eu}$ & n. d. & n. d. & n. d. & n. d. & 2.02 & n. d. & 1.54 & 1.33 & 0.93 & 0.91 \\
\hline $\mathrm{Gd}$ & n. d. & n. d. & n. d. & n. d. & 9.59 & n. d. & 5.17 & 5.09 & 3.70 & 2.78 \\
\hline $\mathrm{Tb}$ & n. d. & n. d. & n. d. & n. d. & 1.43 & n. d. & 0.80 & 0.84 & 0.64 & 0.53 \\
\hline Dy & n. d. & n. d. & n. d. & n. d. & 8.32 & n. d. & 4.36 & 4.38 & 3.54 & 2.97 \\
\hline Ho & n. d. & n. d. & n. d. & n. d. & 1.73 & n. d. & 0.88 & 0.85 & 0.68 & 0.54 \\
\hline Er & n. d. & n. d. & n. d. & n. d. & 3.66 & n. d. & 2.61 & 2.73 & 1.97 & 1.54 \\
\hline $\mathrm{Tm}$ & n. d. & n. d. & n. d. & n. d. & 0.72 & n. d. & 0.40 & 0.38 & 0.29 & 0.24 \\
\hline $\mathrm{Yb}$ & n. d. & n. d. & n. d. & n. d. & 3.78 & n. d. & 2.78 & 2.42 & 1.99 & 1.65 \\
\hline $\mathrm{Lu}$ & n. d. & n. d. & n. d. & n. d. & 0.50 & n. d. & 0.41 & 0.40 & 0.26 & 0.26 \\
\hline Mo & 1.0 & $<0.1$ & $<0.1$ & $<0.1$ & $<0.1$ & $<0.1$ & 0.3 & 0.2 & 0.3 & 0.2 \\
\hline $\mathrm{Cu}$ & 7.0 & 12.0 & 11.0 & 13.0 & 7.0 & 14.0 & 1.2 & 1.5 & 5.3 & 12.3 \\
\hline $\mathrm{Pb}$ & 11.0 & 17.0 & 20.0 & 11.0 & 39.0 & 27.0 & 1.2 & 0.7 & 0.9 & 3.8 \\
\hline $\mathrm{Zn}$ & 168 & 80 & 68 & 264 & 149 & 194 & 5 & 5 & 4 & 13 \\
\hline $\mathrm{Ni}$ & 15.0 & 17.0 & 17.0 & 21.0 & 17.0 & 25.0 & 7.1 & 9.5 & 5.1 & 14.6 \\
\hline As & 6.0 & 23.0 & 6.0 & 8.0 & 7.0 & 6.0 & 1.4 & 1.2 & 0.6 & 1.4 \\
\hline
\end{tabular}

n. d. - not determined

negative correlation of $\mathrm{SiO}_{2}$ with $\mathrm{Al}_{2} \mathrm{O}_{3}$ and $\mathrm{CaO}$ (Fig. 6). $\mathrm{K}$-feldspar-bearing mineral assemblages in some calcsilicate rocks are reflected by higher contents of $\mathrm{K}_{2} \mathrm{O}$ (3.1-5.2 wt. \%) and Rb (171-113 ppm). The studied samples can be subdivided into two groups according to the major-element contents, as illustrated in the SACF diagram (Fig. 7a), where $\mathrm{S}=\mathrm{SiO}_{2}, \mathrm{~A}=\mathrm{Al}_{2} \mathrm{O}_{3}, \mathrm{C}=\mathrm{CaO}$ and $\mathrm{F}=\mathrm{FeO}_{\mathrm{t}}+\mathrm{MgO}$. The bulk rock chemistry of the first group is close that of the marlstones. In the ACF diagram, samples of the second group plot between calcareous sediments and metavolcanites (amphibolites). The $\mathrm{TiO}_{2} /$ $\mathrm{Al}_{2} \mathrm{O}_{3}$ ratio for samples from the $\mathrm{PU}$ is slightly lower
$(0.25-0.34)$ than for samples from the other studied units (0.31-0.51). Relatively small differences in the bulk rock chemistry, especially in the $\mathrm{SiO}_{2}, \mathrm{Al}_{2} \mathrm{O}_{3}, \mathrm{CaO}$ and $\mathrm{Fe}_{2} \mathrm{O}_{3}$ contents, may have strongly affected stability of epidote and garnet (Fig 7a).

The variable contents of $\mathrm{Rb}$ (6-171 ppm), $\mathrm{Ba}$ (18-713 ppm) and Sr (245-678 ppm) suggest distinct geochemical evolution and/or protolith chemistry. The low concentrations of some other trace elements, for example Y (16-45 $\mathrm{ppm})$ and $\mathrm{Nb}(5-15 \mathrm{ppm})$, indicate a possible sedimentary origin. Some calc-silicate rocks related to skarns in the $\mathrm{MZ}$ and SU contain higher concentrations of $\mathrm{Zn}, \mathrm{Cu}$, 

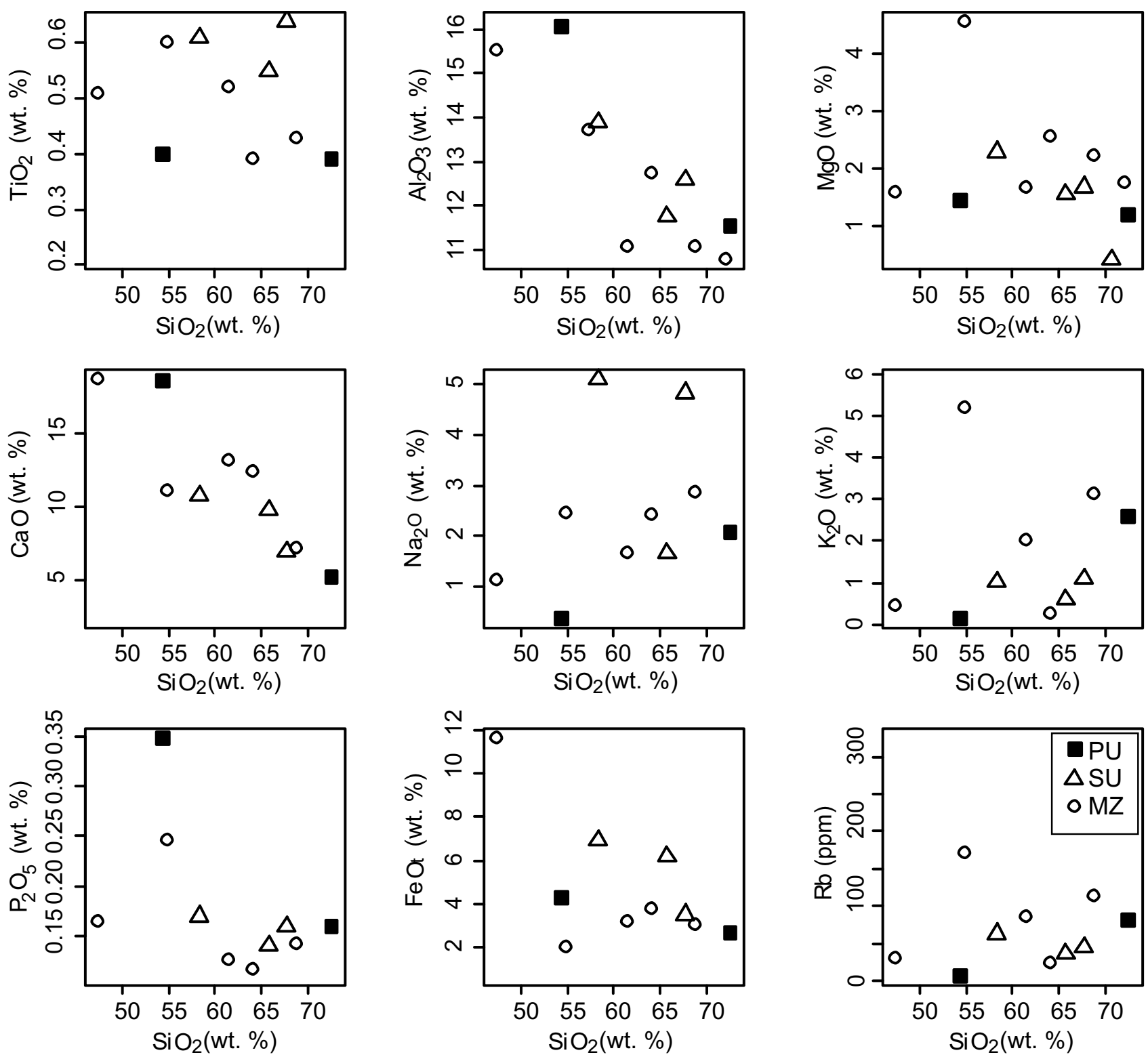

Fig. 6 Variation diagrams of silica vs. selected major, minor and trace elements for calc-silicate rocks from the studied area.

$\mathrm{Ni}$ and $\mathrm{Pb}$ when compared to the other studied samples (Fig. 7b).

Chondrite-normalized REE patterns (Fig. 7c) for samples from the Polička and Svratka units are mutually comparable (total REE contents of 95 and $167 \mathrm{ppm}$ ), with a moderate degree of the LREE/HREE fractionation $\left(\mathrm{La}_{\mathrm{N}} / \mathrm{Yb}_{\mathrm{N}}=6.3-9.6\right)$ and weak negative Eu anomalies $\left(\mathrm{Eu} / \mathrm{Eu}^{*}=0.74-0.93\right)$. One sample has a weak positive $\mathrm{Ce}$ anomaly. The REE patterns for samples from the MZ exhibit a broadly similar shape $\left(\mathrm{La}_{\mathrm{N}} / \mathrm{Yb}_{\mathrm{N}}=5.5-9.7\right)$, however with more pronounced negative $\mathrm{Eu}\left(\mathrm{Eu} / \mathrm{Eu}^{*}=\right.$ $0.56-0.66)$ and sometimes Ce anomaly.

\section{P-T conditions and fluid composition}

\subsection{P-T metamorphic conditions of calc- silicate rocks in the middle subunit of the Polička Unit}

The best-studied samples represent calc-silicate nodules from the middle subunit of the PU, which have composition and metamorphic evolution different from the MZ and SU. The nodules of calc-silicate rocks are enclosed in biotite to muscovite-biotite gneisses. Reaction textures involving clinozoisite and garnet have been described by 

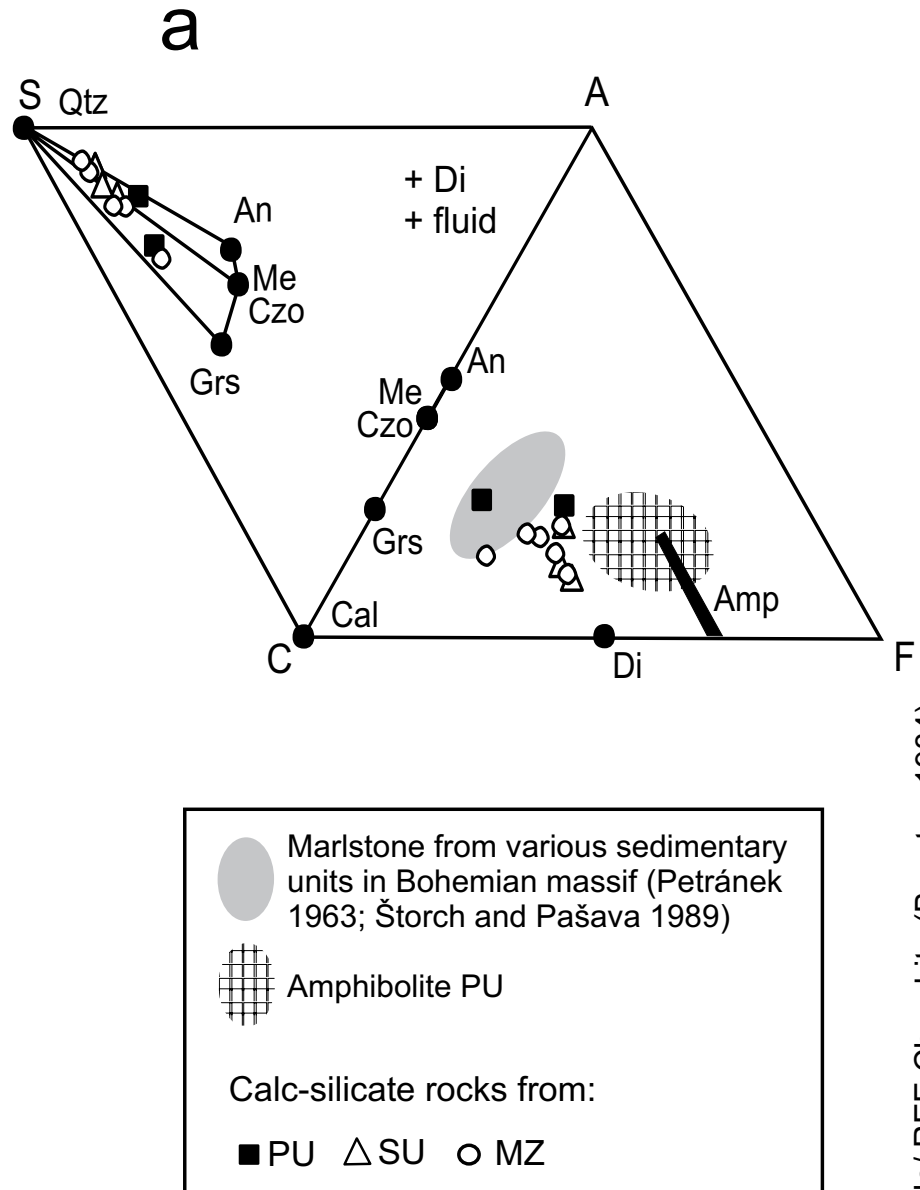
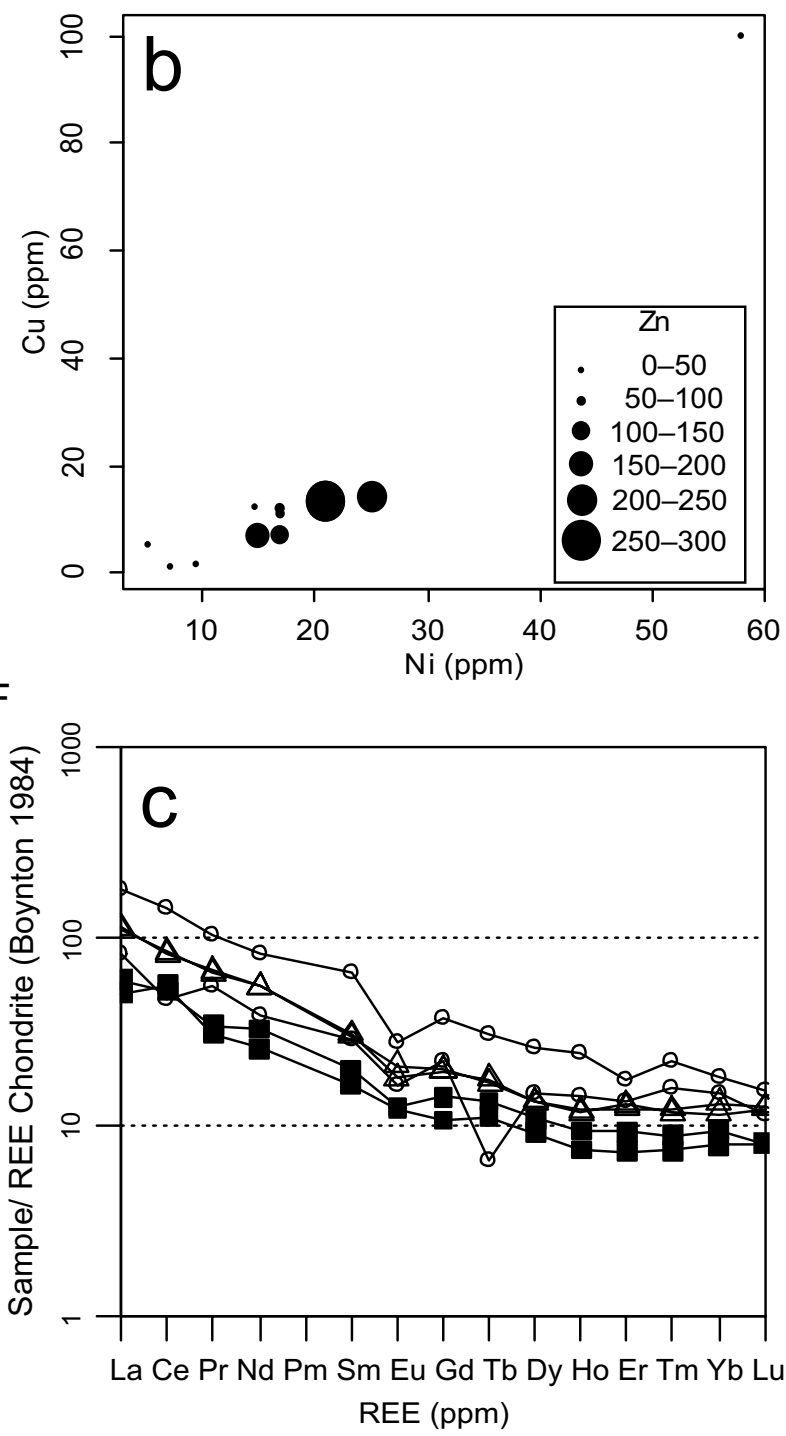

Fig. 7 Chemical composition of calc-silicate rocks from the Moldanubian Zone, Svratka and Polička units: a - chemical composition of samples and probable protoliths in the SACF $\left(\mathrm{SiO}_{2}-\mathrm{Al}_{2} \mathrm{O}_{3}-\mathrm{CaO}-\mathrm{FeO}_{\mathrm{t}}+\mathrm{MgO}\right.$ in mol. \%) diagram; b binary plot $\mathrm{Ni}-\mathrm{Cu}$, size of the plotted circles corresponds to Zn contents; c - Chondrite-normalised REE patterns (Boynton 1984).

Buriánek (2005) for garnet-rich calc-silicate nodules. The presence of clinozoisite together with quartz, plagioclase and garnet (reaction 1) establishes an upper temperature limit of $c .600{ }^{\circ} \mathrm{C}$ at pressure of $6 \mathrm{kbar}$ (Fig. 8a). The P-T conditions calculated by THERMOCALC in the average $\mathrm{P}-\mathrm{T}$ mode are 5 to $7 \mathrm{kbar}$ and 564 to $647^{\circ} \mathrm{C}$ for $\mathrm{X}_{\mathrm{CO}_{2}}=$ 0.05 (Fig. 8b). These are in a good agreement with the data obtained for surrounding metapelites $\left(580-680^{\circ} \mathrm{C}\right.$ and 5-7 kbar; Buriánek 2005). The temperatures calculated using the geothermometer of Ravna (2000) with garnet-clinopyroxene pairs in mutual contact and without evidence for retrogression range from 560 to $722^{\circ} \mathrm{C}$ for nodules in southern part of the PU (e. g. sample 151) and $514-669^{\circ} \mathrm{C}$ in central part of the PU (sample 101). The garnet-clinopyroxene-plagioclase-quartz geobarometer
(Eckert et al. 1991) yields 2-3 kbar for the central PU (sample 101) and 4-5 kbar for the southern part of the middle subunit. These results are about 1-2 kbar lower than those calculated using THERMOCALC. Figure 9 depicts the P-T pseudosection computed by PERPLEX for a bulk composition of the sample 101 over a $\mathrm{T}-\mathrm{X}_{\mathrm{CO}_{2}}$ range of $556-700{ }^{\circ} \mathrm{C}$ and $\mathrm{X}_{\mathrm{CO}_{2}}$ of $0.0-0.5$ at the pressure of $6 \mathrm{kbar}$. The stabilization of the mineral assemblage $\mathrm{Ep} / \mathrm{Czo}+\mathrm{Pl}+\mathrm{Grt}+\mathrm{Cpx}+\mathrm{Qtz}$ requires low $\mathrm{X}_{\mathrm{CO}_{2}}(<0.3)$ and the maximum temperature must be below $680^{\circ} \mathrm{C}$. It is evident that the metamorphic assemblage Ep/Czo $+\mathrm{Pl}$ $+\mathrm{Cal}+\mathrm{Cpx}+$ Qtz observed in the calc-silicate nodules from the northern part of the middle subunit is stable under lover temperatures and/or higher $\mathrm{X}_{\mathrm{CO}_{2}}$ (Fig. 9; sample 101). 

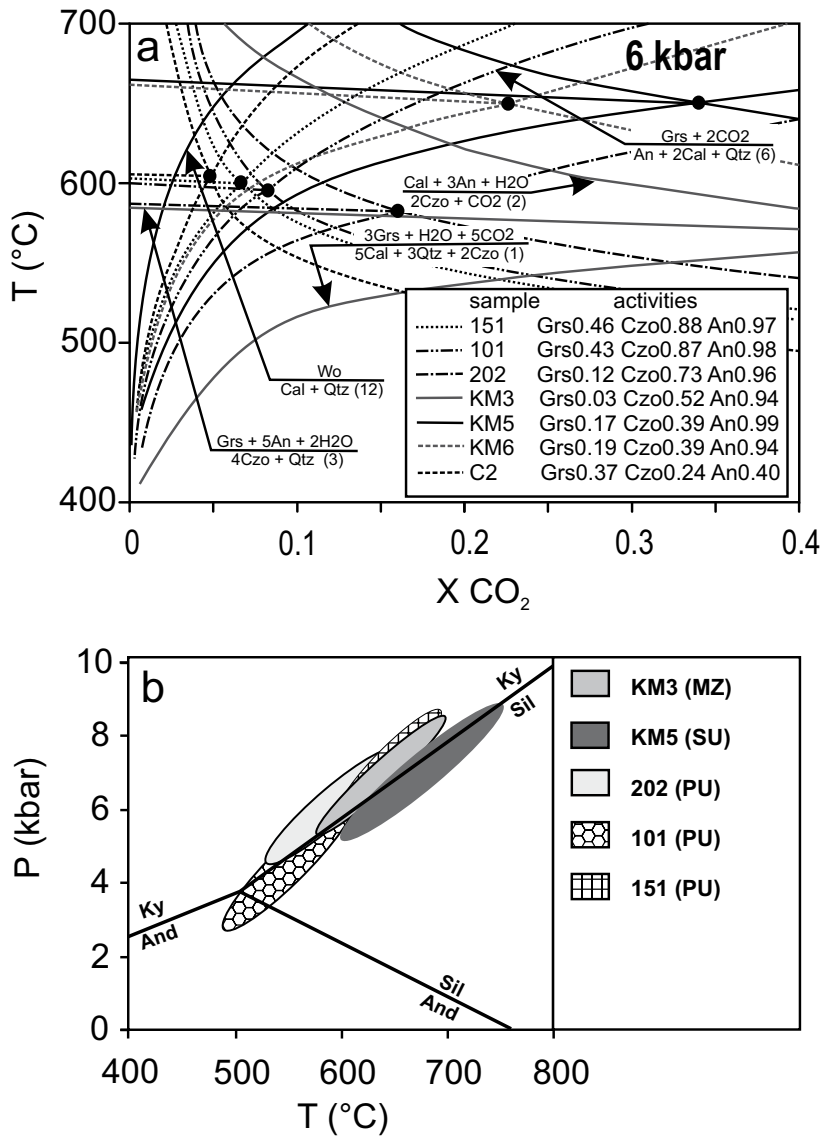

Fig. 8 The isobaric $\mathrm{T}-\mathrm{X}_{\mathrm{CO}}$ plot showing selected metamorphic reactions in the calc-silicate rocks (a) and P-T plot (b) for calc-silicate rocks from the Moldanubian Zone, Svratka and Polička units. Calculated using THERMOCALC; the position of the $\mathrm{Al}_{2} \mathrm{SiO}_{5}$ triple point is taken from Holdaway and Mukhopadhyay (1993).

The mineral assemblage $\mathrm{Cpx}+\mathrm{Cal}+\mathrm{Pl}+\mathrm{Qtz}+\mathrm{Czo}$ in clinopyroxene-bearing calc-silicate nodules from NW part of the PU is not suitable for the thermobarometric calculations. The peak $\mathrm{P}-\mathrm{T}$ metamorphic conditions of $566 \pm 28^{\circ} \mathrm{C}$ and $5 \pm 1 \mathrm{kbar}$ were calculated from the metapelites (Buriánek 2005). The upper metamorphic conditions are limited by the reactions (1) and (2).

These two groups of mineral assemblages in calcsilicate rocks can be interpreted as a result of prograde metamorphism of a similar protolith under the narrow range of $\mathrm{X}_{\mathrm{CO}_{2}}$ and different $\mathrm{P}-\mathrm{T}$ conditions. The northern part of the middle subunit represents a domain affected by metamorphism of a lower grade than the central and southern parts of this subunit. However mineral assemblage without garnet and epidote group minerals $(\mathrm{Qtz}+$ $\mathrm{Cal}+\mathrm{Pl}+\mathrm{Cpx} \pm \mathrm{Amp}$ ) is occasionally present all over the subunit in the carbonate-rich nodules, and can be interpreted in terms of higher $\mathrm{X}_{\mathrm{CO}_{2}}$ during metamorphism (Buriánek 2005).

\subsection{P-T metamorphic evolution of calc- silicate rocks in the lower subunit of the Polička Unit}

The calc-silicate rock bodies are associated with amphibolites, marbles or gneisses in the lower subunit. The surrounding metapelites yield $\mathrm{P}-\mathrm{T}$ conditions of approximately $600-650^{\circ} \mathrm{C}$ and $6-7 \mathrm{kbar}$ (those calculated using THERMOCALC are $624 \pm 29^{\circ} \mathrm{C}$ and $6 \pm 1 \mathrm{kbar}$ for the metapelite near the sample 133 and $654 \pm 29^{\circ} \mathrm{C}$ and $7 \pm$ $1 \mathrm{kbar}$ for the metapelite near the sample 285).

The mineral assemblage typical of bodies in the main part of the lower subunit is $\mathrm{Cpx}+\mathrm{Pl}+\mathrm{Kfs}+\mathrm{Qtz}+\mathrm{Ttn}$ + Amp I (ferrohornblende or ferropargasite) $\pm \mathrm{Cal} \pm$ Czo (samples 163, 102, 133; Fig. 1). The temperatures calculated using the hornblende-plagioclase thermometer (Holland and Blundy 1994) for pressure of $6 \mathrm{kbar}$ are $598-629^{\circ} \mathrm{C}$. The metamorphic $\mathrm{X}_{\mathrm{CO}_{2}}$ for majority of the samples from the lower subunit were usually higher than in the nodules from the middle subunit (Buriánek 2006).
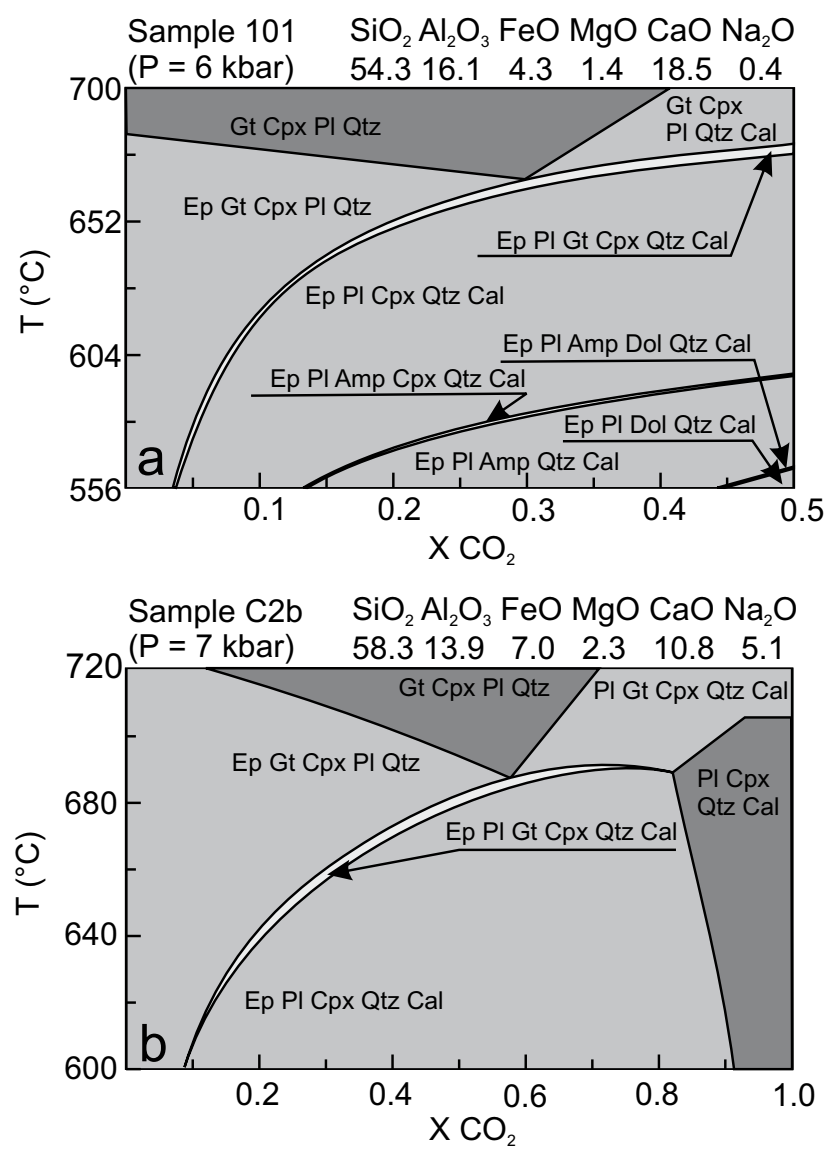

Fig. 9 The $\mathrm{T}-\mathrm{X}_{\mathrm{CO}_{2}}$ pseudosections for calc-silicate rocks from Polička Unit (101) and Svratka Unit (C2b) calculated in the NCFMASCH system using the PERPLEX software. Bulk-rock composition (in wt. \%) and pressure used for the calculation are indicated above the plots. Light, medium and dark grey fields are tri-, four- and five-variant fields, respectively. 
The upper stability of the Cal $+\mathrm{An}+\mathrm{Qtz}$ assemblage is limited by the reaction (6).

The mineral assemblages of calc-silicate rocks from the lower subunit indicate a decrease in the metamorphic grade from SE to NW. The peak $\mathrm{P}-\mathrm{T}$ conditions were probably somewhat higher at the southern edge of the lower subunit (samples 285, 115, 60), because here the calc-silicate rocks sometimes contain garnet. Typical mineral assemblage is $\mathrm{Qtz}+\mathrm{Cpx}+\mathrm{Pl}+\mathrm{Cal}+\mathrm{Ttn} \pm \mathrm{Kfs}$ $\pm \mathrm{Czo} / \mathrm{Ep} \pm \mathrm{Amp} \pm \mathrm{Grt}$ and, occasionally, meionite-rich scapolite. Scapolite is present only in the lithologies lacking garnet. The $\mathrm{Al} / \mathrm{Si}$ ratio (0.65-0.67) is typical of scapolites formed at above $600{ }^{\circ} \mathrm{C}$ (Oterdoom and Wenk 1983). Temperatures of $586-628{ }^{\circ} \mathrm{C}$ were calculated for the surrounding amphibolites for a pressure of $7 \mathrm{kbar}$, based on the hornblende-plagioclase thermometer (Holland and Blundy 1994). The temperature obtained for a pressure of $7 \mathrm{kbar}$, using the garnet-clinopyroxene geothermometer (Ravna 2000), is $672-701^{\circ} \mathrm{C}$ for the sample 115. Layers with clinopyroxene (hedenbergite-rich) and hastingsite require a low oxygen fugacity. Interaction with reduced fluids destabilizes the metamorphic assemblage hedenbergite, magnetite and grossular-andradite garnet and produces hastingsite and quartz (Thomas 1982).

The peak mineral assemblages $(\mathrm{Qtz}+\mathrm{Cpx}+\mathrm{Pl}+\mathrm{Cal}$ $+\mathrm{Ttn} \pm \mathrm{Kfs} \pm \mathrm{Czo} / \mathrm{Ep}$ ) for nearly all the calc-silicate rocks in the lower subunit were partially affected by retrograde metamorphism. The youngest assemblage is represented by clinozoisite-epidote, actinolite (Amp II), albite, calcite or chlorite. The bulk of epidote group minerals are produced due to reversal of the reaction (2) during the retrogression.

\subsection{P-T metamorphic evolution of calc- silicate rocks in the Svratka Unit and the Moldanubian Zone}

In both units, garnet is present predominantly in the calc-silicate rocks associated with skarns. According to Pertoldová (1986) and Drahota et al. (2005), skarns from both units indicate a metamorphic decompression (620-750 $\left.{ }^{\circ} \mathrm{C}, 6-8 \mathrm{kbar}\right)$ following HP-HT regional metamorphism $\left(\right.$ c. $800^{\circ} \mathrm{C}$ and $\left.12 \mathrm{kbar}\right)$. The $\mathrm{P}-\mathrm{T}$ conditions estimated from garnet-bearing calc-silicate rocks are consistent with the younger regional metamorphic conditions obtained from skarns.

Calc-silicate rocks from the SU associated with skarns are characterized by the Grt $+\mathrm{Cpx}+\mathrm{Ttn}+\mathrm{Pl} \pm \mathrm{Kfs} \pm$ $\mathrm{Amp} \pm \mathrm{Bt} \pm \mathrm{Ep} \pm$ Czo mineral assemblage. The metamorphic conditions of $678 \pm 65^{\circ} \mathrm{C}$ and $7 \pm 2 \mathrm{kbar}$ for $\mathrm{X}_{\mathrm{CO}_{2}}=$ 0.05 were calculated for the equilibrated matrix mineral assemblage using THERMOCALC (sample KM5, Fig. 1). The same mineral assemblage yielded a temperature of $490^{\circ} \mathrm{C}$ using the garnet-clinopyroxene geothermometer
(Ellis and Green 1979) and a pressure of 5 kbar using the clinopyroxene-plagioclase geobarometer (Ellis 1980). At temperatures lower than $730^{\circ} \mathrm{C}$ and $\mathrm{X}_{\mathrm{CO}_{2}}$ below 0.6, the assemblage $\mathrm{Czo} / \mathrm{Ep}+\mathrm{Cpx}+\mathrm{Pl}+\mathrm{Qtz}$ is predicted in the $\mathrm{P}-\mathrm{T}$ pseudosection in the model system NCFMASH for the sample C2b (Fig 9). As shown in Figs 8a and 9 , higher pressure (7 kbar) and/or higher Fe content in studied samples (mainly in epidote group minerals) shift the epidote-out reaction (2) towards higher temperature and $\mathrm{X}_{\mathrm{CO}_{2}}$. For the peak mineral assemblage $\mathrm{Grt}+\mathrm{Cpx}+$ $\mathrm{Pl} \pm \mathrm{Scp} \pm \mathrm{Ttn}$ in garnet-rich calc-silicate rock associated with skarn from locality KM3 in MZ, the pressure and temperature conditions of $637 \pm 49^{\circ} \mathrm{C}$ and $7 \pm 1 \mathrm{kbar}$ for $\mathrm{X}_{\mathrm{CO}_{2}}=0.05$ were calculated using THERMOCALC. The garnet-clinopyroxene geothermometer (Ellis and Green 1979) and the clinopyroxene-plagioclase geobarometer (Ellis 1980) yielded $\mathrm{P}-\mathrm{T}$ conditions of $c .637^{\circ} \mathrm{C}$ and 5 kbar (3 kbar using geobarometer of Eckert et al. 1991). Textural equilibrium between plagioclase and scapolite suggests that the scapolite-forming reaction was (5).

Many studied samples exhibit the reversal of the reaction (1) and/or (3) locally accompanied by the reaction (2) reversal. These reactions can be interpreted as being the result of decreasing temperature and/or pressure together with decreasing $\mathrm{X}_{\mathrm{CO}_{2}}$ in the coexisting fluid phases during the exhumation of the SU and the MZ.

Clinopyroxene-bearing calc-silicate rocks from the $\mathrm{SU}$ contain $\mathrm{Cpx}+\mathrm{Pl}+\mathrm{Ttn} \pm \mathrm{Qtz} \pm \mathrm{Amp} \pm \mathrm{Czo} \pm \mathrm{Cal} \pm$ $\mathrm{Bt} \pm \mathrm{Kfs}$. The $\mathrm{X}_{\mathrm{CO}_{2}}$ during prograde metamorphism was probably in the many studied garnet-free samples higher than in the garnet-bearing rocks, because calcite was often found at the contact with plagioclase (reaction 2) and clinozoisite is present as inclusions in plagioclase. Maximum $\mathrm{T}-\mathrm{X}_{\mathrm{CO}_{2}}$ conditions for many samples are limited by the reaction (3). Clinozoisite porphyroblasts with calcite and plagioclase inclusions from other samples (calcite poor) can be interpreted as a result of reaction (2) reversal. The youngest tremolite partially replaced diopside in most samples of the calc-silicate rocks from all the studied units, which can reflect the retrograde metamorphism under greenschist-facies conditions (reaction 7).

The most common mineral assemblage in calc-silicate rocks from the $\mathrm{MZ}(\mathrm{Cpx}+\mathrm{Ttn}+\mathrm{Pl}+\mathrm{Kfs} \pm \mathrm{Amp} \pm \mathrm{Bt}$ $\pm \mathrm{Ep}$ ) is not suitable for constraining the $\mathrm{P}-\mathrm{T}$ conditions (samples KM1, KM2, KM3, KM9, KM9b; Tab. 1). Some calc-silicate rocks are associated with marble in the MZ (KM9, KM9b; Tab. 1). Metamorphic mineral assemblages of marbles $(\mathrm{Cal}+\mathrm{Phl}+\mathrm{Fo} \pm \mathrm{Sp} \pm \mathrm{Tr} \pm \mathrm{Dol}$ \pm Chu) were studied by Novák (1989) and the estimated maximum metamorphic conditions are $\mathrm{T}=660^{\circ} \mathrm{C}$ and $\mathrm{P}$ $=6 \mathrm{kbar}\left(\mathrm{M}_{1}\right)$. The metamorphic assemblage $\mathrm{Cpx}+\mathrm{Pl}+$ $\mathrm{Kfs}+\mathrm{Qtz}+\mathrm{Bt} \mathrm{I}$ in the calc-silicate rocks from Studnice corresponds to this metamorphism. The younger mineral assemblage (Amp $+\mathrm{Czo}+\mathrm{Pl}+\mathrm{Bt}$ II) can be linked to 
the HT-LP metamorphism $\mathrm{M}_{2}$ in the surrounding marbles (according to Novák 1989: $\mathrm{P}=2 \mathrm{kbar}, \mathrm{T}=550{ }^{\circ} \mathrm{C}$ and $\left.\mathrm{X}_{\mathrm{CO}_{2}}<0.1\right)$. The $\mathrm{M}_{3}$ retrograde metamorphism produced chlorite replacing biotite and amphibole. Several $\mathrm{cm}$ thick zones with strongly sericitized plagioclase are locally present.

\section{Discussion}

\subsection{Protolith of calc-silicate rocks}

Geochemical data suggest that the sedimentary protolith of the calc-silicate rocks from all the studied units was probably similar, corresponding to marlstones or altered intermediate-basic tuffs (Fig. 7a). Studied samples show wide range of $\mathrm{Al}_{2} \mathrm{O}_{3}$ (11-16 wt. \%) and $\mathrm{SiO}_{2}(47-73$ wt. \%) contents. Garnet-rich samples are characterized by lower $\mathrm{Na}_{2} \mathrm{O}$ contents and lower $\mathrm{MgO} /\left(\mathrm{MgO}+\mathrm{FeO}_{\mathrm{t}}\right)$ ratios when compared to pyroxene-bearing samples (0.4-1.7 vs. $1.6-5.1$ and $0.12-0.25$ vs. $0.25-0.69$, respectively). Lower proportion of albite component in the plagioclase and higher Fe contents in the rock-forming minerals probably stabilized the $\mathrm{Mg}-\mathrm{Fe}-\mathrm{Ca}$ garnet.

\subsection{Comparison of $P-T-X$ conditions of calc- silicate rocks in the eastern part of the Bohemian Massif}

The observed changes in the mineral assemblage of nodules in the middle subunit of the PU seem to reflect an increase in metamorphic grade towards the SSW. Minerals in the matrix of calc-silicate rocks correspond to nearly peak $\mathrm{P}-\mathrm{T}$ conditions and indicate very low $\mathrm{X}_{\mathrm{CO}}$. Estimated $\mathrm{P}-\mathrm{T}$ conditions (temperature between $<560$ and $650{ }^{\circ} \mathrm{C}$ and pressure $\left.6-7 \mathrm{kbar}\right)$ are in good agreement with data obtained from the surrounding metapelites (Buriánek et al. 2009a). The upper temperature stability limit of coexisting quartz and clinozoisite is $c .650^{\circ} \mathrm{C}$ and $\mathrm{X}_{\mathrm{CO}_{2}}$ $<0.3$ for pressure of $c .6 \mathrm{kbar}$ (sample 101; Fig. 9). The nodules without garnet in the NW and NE parts of the PU indicate lower metamorphic temperature as demonstrated by the stability of the clinozoisite + quartz + calcite assemblage (Figs 8b, 9).

Regional metamorphic peak conditions of $580-680^{\circ} \mathrm{C}$ and 5-7 kbar have been reported for rocks surrounding the calc-silicate bodies in the lower subunit of the PU (Buriánek et al. 2009a). Under such P-T conditions, calcite, epidote group minerals, plagioclase and quartz should coexist with fluid compositions that are systematically higher in $\mathrm{X}_{\mathrm{CO}_{2}}$ than those estimated for nodules of the calc-silicate rock (Buriánek 2006). The only exception is represented by garnet-rich calc-silicate rock body (sample 115), which is associated with metapelites.
The matrix mineral assemblage of garnet-rich calcsilicate rocks of the $\mathrm{MZ}$ and $\mathrm{SU}$ reflects $\mathrm{P}-\mathrm{T}$ conditions estimated in surrounding metapelites $\left(750^{\circ} \mathrm{C}\right.$ with $7-10$ kbar and $640-680{ }^{\circ} \mathrm{C}$ with $5-7 \mathrm{kbar}$, respectively). Lower $\mathrm{Na}$ contents in matrix clinopyroxene compared to clinopyroxene inclusions from the garnet core can be interpreted as being the result of post-peak decompression during exhumation. This is in good agreement with the evolution of the associated skarns (Pertoldová et al. 2009). The lower temperature stability limit of the mineral assemblage Grs $+\mathrm{An}+\mathrm{Qtz}+\mathrm{Czo}$ is defined by the reaction (1). The upper temperature limit for majority of garnet-bearing assemblages in calc-silicate rocks is imposed by the univariant reaction (3). For the studied samples, position of metamorphic reaction (3) in isobaric $\mathrm{T}-\mathrm{X}_{\mathrm{CO}_{2}}$ diagram calculated at $6 \mathrm{kbar}$ (Fig. 8a) shows wide range of temperatures $\left(570-670^{\circ} \mathrm{C}\right)$. In the NCFMASH system (Fig. 9) that closely approximates the composition of the reported calc-silicate rocks, the stability field of Czo/Ep $+\mathrm{Cpx}+\mathrm{Grt}+\mathrm{Pl}+$ Qtz-bearing assemblage is relatively wide. Ferromagnesious phases in the studied rocks are rich in both $\mathrm{Mg}$ and $\mathrm{Fe}$ end-members, usually with predominance of $\mathrm{Mg}$. For majority of the studied rocks, formation of metamorphic assemblage Czo/Ep + $\mathrm{Cpx}+\mathrm{Grt}+\mathrm{Pl}+\mathrm{Qtz}$ is restricted to the $\mathrm{X}_{\mathrm{CO}_{2}}$ below 0.6 (for sample C2b in Fig. 9) due to reactions (1) and (3). However, in the calc-silicate rocks with low quartz and calcite contents, epidote group minerals can be stabilized in the wide range of $\mathrm{T}-\mathrm{X}_{\mathrm{CO}_{2}}$ conditions (Fig. 8a). In this case garnet can be produced by other garnet-forming reactions such as $\mathrm{Ep}+\mathrm{Chl}+\mathrm{Qtz}=\mathrm{Grt}+\mathrm{H}_{2} \mathrm{O}$ or Ep $=$ $\mathrm{Grs}+\mathrm{Alm}+\mathrm{H}_{2} \mathrm{O}+\mathrm{O}_{2}$.

Matrix mineral assemblage of the pyroxene-rich calcsilicate rocks $(\mathrm{Qtz}+\mathrm{Cpx}+\mathrm{Pl} \pm \mathrm{Kfs} \pm \mathrm{Amp} \pm \mathrm{Cal} \pm \mathrm{Scp} \pm$ $\mathrm{Ttn})$ from the $\mathrm{MZ}$ and $\mathrm{SU}$ corresponds to peak metamorphic conditions in surrounding marbles and migmatites, and is very similar to assemblages in calc-silicate bodies in the lower PU subunit. The primary minerals may have been partially replaced by post-peak metamorphic assemblage, with amphibole and clinozoisite-epidote formed under equilibrium with $\mathrm{H}_{2} \mathrm{O}$-rich fluids. Fine-grained mixture of chlorite and calcite replacing clinopyroxene, and aggregates of albite and/or epidote replacing $\mathrm{Ca}-$ rich plagioclase, could have resulted from retrograde metamorphism.

One possible explanation for the presence of the two distinct peak metamorphic assemblages is that $\mathrm{X}_{\mathrm{CO}_{2}}$ was higher in the pyroxene-rich rather than in the associated garnet-rich calc-silicate rocks. This assumption was confirmed by the occurrence of mineral assemblages with garnet (sample KM13) and/or wollastonite in the calcsilicate rocks from $\mathrm{MZ}$ and $\mathrm{SU}$ metamorphosed at higher activity of $\mathrm{H}_{2} \mathrm{O}$ in the metamorphic fluids (e.g. Novák and Houzar 1996). Under amphibolite-facies conditions (c. 


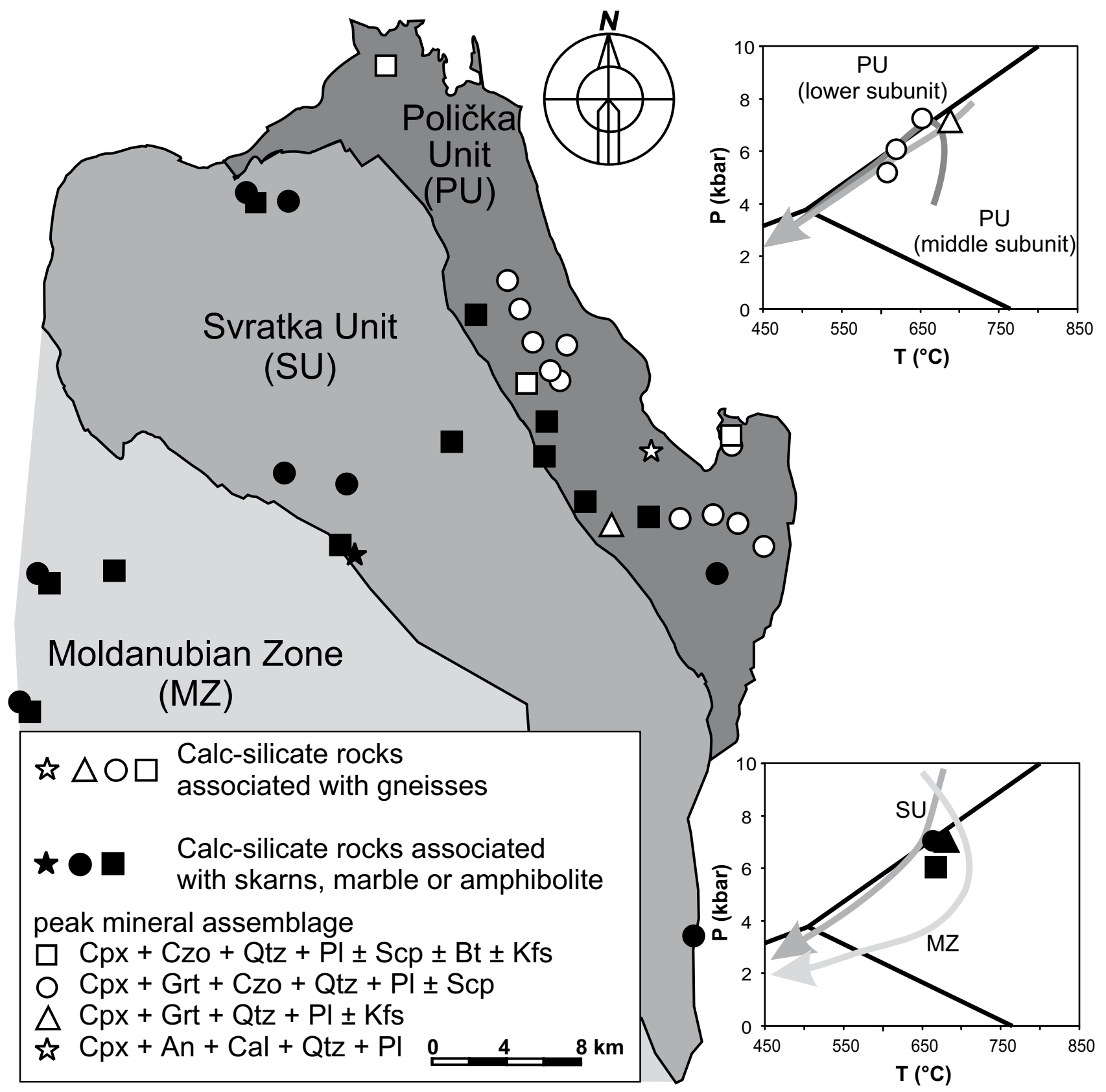

Fig. 10 Simplified map of the studied region, depicting the distribution of the mineral assemblages in calc-silicate rocks of the Moldanubian Zone, Svratka and Polička units. The rocks are subdivided according to their mineralogy and host-rock type (gneisses, skarns, marbles and amphibolites). The P-T paths indicate metamorphic evolution of metapelites in the studied units according to Büttner and Kruhl (1997), Racek et al. (2006) and Buriánek et al. (2009a).

$\left.6 \mathrm{kbar}, \mathrm{c.} 600^{\circ} \mathrm{C}\right)$, the presence of wollastonite suggests very low $\mathrm{X}_{\mathrm{CO}_{2}}<0.05\left[\right.$ Fig. 8a, $\mathrm{Cal}+\mathrm{Qtz}=\mathrm{Wo}+\mathrm{CO}_{2}$ (12)]. Wollastonite decarbonation reactions represent a petrological fingerprint of aqueous fluids infiltration during metamorphism (e.g. Ferry 1991, 1994).

The occurrence of actinolite, chlorite and partly also of clinozoisite resulted from later retrograde metamorphism usually accompanied with higher activity of $\mathrm{H}_{2} \mathrm{O}$ in the metamorphic fluids. For example, textural observations confirm the breakdown of grossular-rich garnet to epidote group minerals, plagioclase and quartz. Reaction textures around garnet were produced by the reaction (1) and are consistent with cooling (with or without change in $\mathrm{P}$ or $\left.\mathrm{X}_{\mathrm{CO}_{2}}\right)$. 


\subsection{Factors controlling the presence of garnet in calc-silicate rocks}

Mineral assemblage $\mathrm{Cpx}+\mathrm{Czo}+\mathrm{Grt}+\mathrm{Pl}+\mathrm{Qtz}$ is relatively widespread in all the studied units. This mineral assemblage has formed in most of the rocks at the expense of calcite by the model reaction (1). It is evident from Fig. 8a that this assemblage grew mostly in equilibrium with water-rich fluids. The presence of clinozoisite in contact with quartz is typical of the majority of the studied samples. This observation suggests that the reaction (3) was not crossed. The lack of evidence for the operation of the wollastonite-producing reaction $\mathrm{Cal}+\mathrm{Qtz}=$ $\mathrm{Wol}+\mathrm{CO}_{2}$ (12) at most of the studied localities excludes an extremely water-rich fluid composition (Fig. 8a)

Irregular distribution of garnet (Fig. 10) in the three studied units can be explained by combination of at least three main factors.

The first is locally higher $\mathrm{X}_{\mathrm{CO} 2}$ in metamorphic fluids as a consequence of higher carbonate content in the protolith. The occurrence of marble bodies in the lower subunit of the PU and SU was probably of substantial significance for the high $\mathrm{CO}_{2}$ content in the metamorphic fluid. Secondly, rocks from the lower PU subunit, SU and MZ were affected by higher pressures, usually accompanied by higher temperature. The calc-silicate samples indicate a decompressional $\mathrm{P}-\mathrm{T}$ path (Fig. 10) at least from the higher-pressure part of the amphibolitefacies metamorphic field (Pitra and Guiraud 1996; Buriánek et al. 2009b). The matrix mineral assemblage of the calc-silicate rocks represents the middle amphibolite facies $\mathrm{P}-\mathrm{T}$ conditions $\left(640-680^{\circ} \mathrm{C}\right.$ and 6-7 kbar). During decompression, several mineral reactions occurred between garnet, epidote, plagioclase, diopside, amphibole, calcite and quartz in the presence of a pore fluid. The epidote group minerals were produced mainly due to the metamorphic reaction (3) and their growth was locally accompanied by the appearance of amphibole and by the change in plagioclase chemical composition. The third most important factor is probably the chemical composition of the protolith, because garnet is present in rocks with specific bulk rock chemistry (i.e. low Fe and high $\mathrm{Ca}$ and $\mathrm{Al}$ contents). Occurrence of the mineral assemblage Czo $+\mathrm{Grt}+\mathrm{Pl}+\mathrm{Qtz}+\mathrm{Cpx}$ is restricted to the middle amphibolite facies and low $\mathrm{X}_{\mathrm{CO} 2}$, nevertheless higher content of pistacite component in epidote may significantly extend its stability field (Fig. 9).

\section{Conclusions}

The bulk rock chemistry and mineralogy of the calc-silicate rocks indicate that they were derived from silica-rich calcareous protoliths, for example marlstones or altered tuffs. Two different groups of calc-silicate rocks in all the studied metamorphic units are distinguished according to the presence/absence of garnet. The spatial distribution of garnet-bearing calc-silicate rocks in the studied units depends mainly on the bulk rock chemistry and fluid composition during metamorphic evolution. Most of the studied samples of calc-silicate rocks contain mineral assemblages in equilibrium with $\mathrm{a}_{2} \mathrm{O}-\mathrm{CO}_{2}$ fluid, characterized by low $\mathrm{X}_{\mathrm{CO} 2}$ mole fraction. The dominant garnet-producing reaction was calcite + quartz + clinozoisite $=$ garnet $+\mathrm{H}_{2} \mathrm{O}+5 \mathrm{CO}_{2}$. However, the presence of $\mathrm{Fe}$ and other components in the studied rocks affected significantly the stability of the Grt-Czo/Ep-Pl-Qtz-Cpx mineral assemblage allowing its formation at higher $\mathrm{P}-\mathrm{T}-$ $\mathrm{X}_{\mathrm{CO} 2}$ than it would occur in the $\mathrm{CASCH}$ system with pure clinozoisite and grossular end-members. In the Fe-rich systems, epidote group minerals were probably consumed also by other garnet-forming reactions as e.g. Ep $+\mathrm{Chl}+$ $\mathrm{Qtz}=\mathrm{Grt}+\mathrm{H}_{2} \mathrm{O}$ or $\mathrm{Ep}=\mathrm{Grs}+\mathrm{Alm}+\mathrm{H}_{2} \mathrm{O}+\mathrm{O}_{2}$.

Temperatures of $560-680{ }^{\circ} \mathrm{C}$ and pressures of 5-7 kbar were calculated for calc-silicate rocks from the middle PU subunit. These $\mathrm{P}-\mathrm{T}$ conditions are similar to those obtained for surrounding metapelites. Metamorphic grade in the calc-silicate rocks from the PU increases towards the SSW; the temperature peak of the Variscan regional metamorphism was followed by a younger LTLP greenschist-facies metamorphism.

The majority of the calc-silicate rocks from the lower PU subunit does not contain garnet, although the surrounding metapelites indicate similar metamorphic temperatures and slightly higher pressures $\left(600-650{ }^{\circ} \mathrm{C}\right.$ and 6-7 kbar) compared to rocks from the middle subunit. This fact can be explained by differences in the metamorphic fluids composition. Fluid compositions estimated for metamorphism of the calc-silicate rock nodules in the middle PU subunit are systematically lower in $\mathrm{X}_{\mathrm{CO}_{2}}$ than those in equilibrium with the metamorphic assemblage of the calc-silicate rocks in the lower PU subunit.

The metamorphic $\mathrm{P}-\mathrm{T}$ path for the calc-silicate rocks in the $\mathrm{MZ}$ and $\mathrm{SU}$ reflects post-peak metamorphic decompression after the HT-HP regional metamorphism. The $\mathrm{P}-\mathrm{T}$ conditions obtained for calc-silicate rocks in the $\mathrm{MZ}$ and $\mathrm{SU}$ are $640-680{ }^{\circ} \mathrm{C}$ and 5-7 kbar. The mineral assemblage of these rocks is interpreted to have been formed due to an influx of water-rich fluids from the surrounding metapelites. The presence of younger actinolite, chlorite and clinozoisite in most of the samples could have resulted from later retrograde cooling with, or without, change in $\mathrm{P}$ or $\mathrm{X}_{\mathrm{CO}_{2}}$.

Acknowledgements The authors wish to thank F. Gallien and an anonymous reviewer for critical review of the manuscript. The work was conducted with the financial support of the Czech Ministry of Environment, Project 
No. 6352 'Correlation of lithologically contrasting rocks from the crystalline units on the NE boundary of Moldanubicum' as well as the Grant Agency of the Charles University, Project No. 81909: 'The emplacement mechanism of individual plutons in northern part of the moldanubia; implications for tectonic evolution of the eastern margin of the Bohemian Massif'. We are grateful to J. Konopásek for his comments and suggestions during the manuscript preparation.

Electronic supplementary material. The GPS coordinates of the studied samples, and the table of whole-rock geochemical compositions (Tab. 6) are available online at $h$ ttp://dx.doi.org/10.3190/jgeosci.051.

\section{References}

Baumgartner LP, Ferry JM (1991) A model for coupled fluid-flow and mixed-volatile mineral reactions with applications to regional metamorphism. Contrib Mineral Petrol 106: 273-285

BOYNTON WV (1984) Cosmochemistry of the rare earth elements: meteorite studies. In: HENDERSON PE (ed) Rare Earth Element Geochemistry. Elsevier, Amsterdam, pp 63-114

Buick I S, Cartwright I (1994) Significance of early scapolite in greenschist-facies marbles from the Reynolds Range Group, central Australia. J Geol Soc, London 151: 803-812

BuRIÁNEK D (2005) Nodules of calc-silicate rocks from Polička Crystalline Unit and their lithologic significance. Acta Mus Moraviae, Sci geol 90: 121-146 (in Czech)

BuRIÁNeK D (2006) Calc-silicate rocks from Polička Crystalline Unit. Acta Mus Moraviae, Sci geol 91: 191-206 (in Czech)

BuRIÁNEK D (2008) Mafic enclaves from the diatexite migmatites in the Svratka Crystalline Complex. Acta Mus Moraviae, Sci geol 93: 137-150 (in Czech)

BuriáneK D, ČopJakovÁ R (2008) Tourmaline from the mica schist of the Svratka Crystalline complex. Acta Mus Moraviae, Sci Geol 93: 61-79 (in Czech)

BuriáNeK D, NĚMeČKovÁ M, HANŽL P (2003) Petrology and geochemistry of the plutonic rocks in the Polička and Zábřeh crystalline units (NE Bohemian Massif). Bull Geosci 78: 9-22

Buriánek D, Břízová E, Čech S, Čurda J, Fürych V, HANŽL P, KirChNER K, LySENKo V, RošTínsKÝ P, RÝdA K, Skácelová D, Skácelová Z, Verner K, Vít J (2009a) Basic geological map ČR 1:25000 with explanations, 24-112 Jedlová. Czech Geological Survey, Prague, pp 1-76 (in Czech)

Buriánek D, Hrdličková K, Hanžl P (2009b) Geological position and origin of augen gneisses from the
Polička Unit, eastern Bohemian Massif. J Geosci 54: 201-219

Buriánek D, Verner K, Hanžl P, Krumlová H (2009c) Ordovician metagranites and migmatites of the Svratka and Orlice-Sněžník units, northeastern Bohemian Massif. J Geosci 54: 181-200

Büttner S, KRUhl JH (1997) The evolution of a lateVariscan high-T/low-P region: the southeastern margin of the Bohemian Massif. Geol Rundsch 86: 21-38

ConNolly JAD (2005) Computation of phase equilibria by linear programming: a tool for geodynamic modeling and its application to subduction zone decarbonation. Earth Planet Sci Lett 236: 524-541

Dale J, Holland T, Powell R (2000) Hornblende-garnetplagioclase thermobarometry: a natural assemblage calibration of the thermodynamics of hornblende. Contrib Mineral Petrol 140: 353-362

DASGUPTA S, PAL S (2005) Origin of grandite garnet in calc-silicate granulites: mineral-fluid equilibria and petrogenetic grids. J Petrol 46: 1045-1076

Donohue C.L., Essene E.J. (2000) An oxygen barometer with the assemblage garnet-epidote. Earth Planet Sci Lett 181: 459-472

Drahota P, Pertold Z, Pudilová M (2005) Genesis of regionally metamorphosed skarns from the Bohemian Massif: contact metasomatic versus sedimentary-exhalative. In: MaO J, BiERLEIn FP (eds) Mineral Deposit Research: Meeting the Global Challenge, Beijing, August 18-21. Proceedings of the Eighth Biennial SGA Meeting, Berlin, pp 377-380

DROOP GTR (1987) A general equation for estimating $\mathrm{Fe}^{3+}$ concentrations in ferromagnesian silicates and oxides from microprobe analyses, using stoichiometric criteria. Mineral Mag 51: 431-435

Eckert JO, Newton RC, Kleppa OJ (1991) The $\Delta \mathrm{H}$ of reaction and recalibration of the garnet-pyroxeneplagioclase-quartz geobarometers in the CMAS system by solution calorimetry. Amer Miner 76: 148-160

ELLIS DJ (1978) Stability and phase equilibria of chloriteand carbonate-bearing scapolites at $7500{ }^{\circ} \mathrm{C}$ and 4000 bar. Geochim Cosmochim Acta 42: 1271-1281

ElLIS DJ (1980) Osumilite-sapphirine-quartz granulites from Enderby Land, Antarctica: P-T conditions of metamorphism, implications for garnet-cordierite equilibria and the evolution of the deep crust. Contrib Mineral Petrol 74: 201-210

ElLis DJ, GreEn DH (1979) An experimental study of the effect on $\mathrm{Ca}$ upon garnet-clinopyroxene $\mathrm{Fe}-\mathrm{Mg}$ exchange equilibria. Contrib Mineral Petrol 71: 13-22

FERRY JM (1991) Dehydration and decarbonation reactions as a record of fluid infiltration. In: KerRICK DM (ed) Contact Metamorphism. Reviews in Mineralogy and Geochemistry 26: 351-393

FERRY JM (1994) Overview of the petrological record of 
fluid flow during regional metamorphism in northern New England. Amer J Sci 294: 905-988

Franke W (2000) The mid-European segment of the Variscides: tectonostratigraphic units, terrane boundaries and plate tectonic evolution. In Franke W, HAAK W, Oncken O, Tanner D (eds) Orogenic Processes: Quantification and Modelling in the Variscan Belt. Geol Soc London Spec Publ 179: 35-63

HanžL P, HrdLIČKovÁ K, Vít J (2006) Geological map ČR $1: 25$ 000, 24-132, Dalečín. Unpublished manuscript, Czech Geological Survey

Hanžl P, Buriánek D, Čurda J, Fürich V, HrdlčKová K, Kirchner K, Lysenko V, Mrnková J, Otava J, PerTOldová J, RoštínskÝ P, RÝdA K, Skácelová Z, Vít J, ZELENKA P (2008a) Basic geological map ČR 1:25000 with explanations, 14-333 Svratka. Czech Geological Survey, Prague, pp 1-72 (in Czech)

Hanžl P, HrdličKová K, Bešta J, BlažKová Š, BŘízová E, Dosbaba M, Fürych V, Kirchner K, Kryštofová E, Lysenko V, Pertoldová J, Roštínský P, Rýda K, Skácelová Z, Skácelová D, Tajčmanová L, Vít J, ZAVŘELOVÁ A, ŽÁČKovÁ E (2008b) Basic geological map ČR 1:25000 with explanations, 24-113 Nové Město na Moravě. Czech Geological Survey, Prague, pp 1-62 (in Czech)

HARLEY SL, BUICK IS (1992) Wollastonite-scapolite assemblages as indicators of granulite pressure-temperaturefluid histories: the Rauer Group, East Antarctica. J Petrol 33: 693-728

Holdaway MJ, MukHopadHyAy B (1993) A reevaluation of the stability relations of andalusite: thermochemical data and phase diagram for the aluminium silicates. Amer Miner 78: 298-315

Holland TJB, Blundy J (1994) Non-ideal interactions in calcic amphiboles and their bearing on amphiboleplagioclase thermometry. Contrib Mineral Petrol 116: 433-447

Holland TJB, Powell R (1996) Thermodynamics of orderdisorder in minerals. II. Symmetric formalism applied to solid solutions. Amer Miner 81: 1425-1437

Holland TJB, Powell R (1998) An internally consistent thermodynamic data set for phases of petrological interest. J Metamorph Geol 16: 309-343

Holland TJB, Baker J, Powell R (1998) Mixing properties and activity-composition relationships of chlorites in the system $\mathrm{MgO}-\mathrm{FeO}-\mathrm{Al}_{2} \mathrm{O}_{3}-\mathrm{SiO}_{2}-\mathrm{H}_{2} \mathrm{O}$. Eur J Mineral 10: 395-406

JANOUŠEK V, FARROW CM, ERBAN V (2006) Interpretation of whole-rock geochemical data in igneous geochemistry: introducing Geochemical Data Toolkit (GCDkit). J Petrol 47: 1255-1259.

КАснці́ V (1999) Relationship between Moldanubicum, the Kutná Hora Crystalline Unit and Bohemicum (central Bohemia, Czech Republic); a result of the polyphase Variscan nappe tectonics. J Czech Geol Soc 44: 201-291

Klemd R, Martin J, Schmidt A, Barton JM Jr (2003) P-T path constraints from calc-silicate metapelitic rocks east of the Venetia kimberlite pipes, Central Zone, Limpopo Belt, South Africa: have these rocks seen granulite-facies conditions? South Afr J Geol 106: 129-148

KRETZ R (1983) Symbols for rock-forming minerals. Amer Miner 68: 277-279

Leake BE, Woolley AR, Arps CES, Birch WD, Gilbert MC, Grice JD, Hawthorne FC, Kato A, Kisch HJ, KrivoviChev VG, Linthout K, Laird J, Mandarino J, Maresch WV, Nickel E. H., Rock NMS, Schumacher JC, Smith DC, Stephenson NCN, UngaretTi L, Whittaker EJW, YouZHi G (1997) Nomenclature of amphiboles. Report of the Subcommittee on Amphiboles of the International Mineralogical Association Commission on New Minerals and Mineral Names. Eur J Mineral 9: 623-651

Melichar R (1993) Structural analysis of relationships between the Polička and Svratka crystalline units. Unpublished $\mathrm{PhD}$ thesis, Charles University, Prague, pp 1-50 (in Czech)

Melichar R, Buriánek D, Břizová E, Buriánková K, Čurda J, Fürych V, HanžL P, Kirchner K, Lysenko V, Mrnková J, RoštínskÝ P, RÝda K, SKácelová Z, Vít J (2008) Explanations to the geological map ČR $1: 25$ 000, 24-111 Sněžné. Czech Geological Survey, Prague, pp 1-63 (in Czech)

Melichar R, HanžL P (1997) Lithotectonic correlation of the Polička and Zábřeh crystalline units. J Czech Geol Soc 42: 64

Mísař Z, Dudek A, Havlena V, Weiss J (1983) Geology of the ČSSR I, Bohemian Massif. SPN, Prague, pp 1-333 (in Czech)

Mísař Z, NekovaŘíí Č, Zelinka P (1995) Geological map ČR $1: 50$ 000, 24-12, Letovice. Czech Geological Survey, Prague (in Czech)

Morimoto N (1988) Nomenclature of pyroxenes. Mineral Mag 52: 535-550

Mrázová Š., BŘízová E, Buriánek D, Fürych V, KadleCová R, Kirchner K, Lysenko V, Otava J, Rambousek P, Roštínský P, Skácelová D, Skácelová Z, Vít J, ZeLENKA P (2008) Explanations to the geological map ČR 1 : 25 000, 13-444 Hlinsko. Czech Geological Survey, Prague, pp 1-68 (in Czech)

Newton R, GolDSmith J (1975) Stability of the scapolite meionite $\left(3 \mathrm{CaAl}_{2} \mathrm{Si}_{2} \mathrm{O}_{8} \mathrm{CaCO}_{3}\right)$ at high pressures and storage of $\mathrm{CO}_{2}$ in the deep crust. Contrib Mineral Petrol 49: 49-62

Newton RC, Charlu TV, Kleppa OJ (1980) Thermochemistry of the high structural state plagioclases. Geochim Cosmochim Acta 44: 933-941

NovÁK M (1989) Metamorphism of dolomitic rocks at the North-East margin of the Moldanubicum. Acta Mus Moraviae, Sci nat 74: 7-51 
NovÁK M, Houzar S (1996) The HT/LP metamorphism of dolomite marbles in the eastern part of the Moldanubicum; a manifestation of heat flow related to the Třebíc Durbachite Massif. J Czech Geol Soc 41: 139-146

O’BRIEN PJ, VRÁNA S (1995) Eclogites with a short-lived granulite-facies overprint in the Moldanubian Zone, Czech Republic - petrology, geochemistry and diffusion modeling of garnet zoning. Geol Rundsch 84: 473-488

OteRDOOM WH, Wenk HR (1983) Ordering and composition of scapolite: field observations and structural implications. Contrib Mineral Petrol 83: 330-341

OwENS BE (2000) High-temperature contact metamorphism of calc-silicate xenoliths in the Kiglapait Intrusion, Labrador. Amer Miner 85: 1595-1605

Pertoldová J (1986) Conditions of Genesis of Skarns at Pernštejn, Županovice and Nové Město pod Smrkem Deposits. Unpublished $\mathrm{PhD}$ thesis, Charles University, Prague, pp 1-86 (in Czech)

Pertoldová J, Týcová P, Verner K, Košuličová M, Pertold Z, Košler J, Konopásek J, Pudilová M (2009) Metamorphic history of skarns, origin of their protolith and implications for genetic interpretation; an example from three units of the Bohemian Massif. J Geosci 54: 101-134

Petrakakis K (1997) Evolution of Moldanubian rocks in Austria: review and synthesis. J Metamorph Geol 15: 203-222

Petránek J (1963) Sedimentary Rocks, Their Composition, Origin and Deposits. ČSAV, Prague, pp 1-720 (in Czech)

Pitra P, Guiraud M (1996) Probable anticlockwise P-T evolution in extending crust: Hlinsko region, Bohemian Massif. J Metamorph Geol 14: 49-60

Powell R, Holland TJB (1988) An internally consistent thermodynamic dataset with uncertainties and correlations: 3: application methods, worked examples and a computer program. J Metamorph Geol 6: 173-204

Racek M, Štípská P, Pitra P, Schulmann K, Lexa O (2006) Metamorphic record of burial and exhumation of orogenic lower and middle crust: a new tectonothermal model for the Drosendorf Window (Bohemian Massif, Austria). Mineral Petrol 68: 221-251

Ravna K (2000) The garnet-clinopyroxene $\mathrm{Fe}^{2+}-\mathrm{Mg}$ geothermometer: an updated calibration. J Metamorph Geol 2: 211

Schulmann K, Kröner A, Wendt I J, Hegner E, Konopásek J, LEXA O, ŚTíPSKÁ P (2005) Chronological constraints on the pre-orogenic history, burial and exhumation of deep-seated rocks along the eastern margin of the Variscan orogen, Bohemian Massif, Czech Republic. Am J Sci 305: 407-448

Shaw RK, ARIMA M (1996) High-temperature metamorphic imprint on calc-silicate granulites of Rayagada, Eastern Ghats, India: implication for the isobaric cooling path. Contrib Mineral Petrol 12: 169-180
StÁrková I, MaceK J (1994) Geological map ČR $1: 50$ 000, 24-13 Bystřice nad Pernštejnem. Czech Geological Survey, Prague (in Czech)

Stárková I, Macek J, Moupic Z (1996) Geological map ČR 1:50 000: 24-11, Nové Město na Moravě. Czech Geological Survey, Prague (in Czech)

Stárková I, Opletal M, Adamovič J, Macek J (1998) Geological map ČR 1:50 000: 14-33, Polička. Czech Geological Survey, Prague (in Czech)

ŠTípská P, Schulmann K, KRÖNer A (2004) Vertical extrusion and middle crustal spreading of omphacite granulite: a model of syn-convergent exhumation (Bohemian Massif, Czech Republic). J Metamorph Geol 22: 179-198

ŠTorCh P, PAŠAVA J (1989) Stratigraphy, chemistry and origin of the Lower Silurian black graptolitic shales of the Prague Basin (Barrandian, Bohemia). Věst Úst Ústř geol 64: 143-162

Štoudová S, Schulmann K, Konopásek J (1999) A contrast between metamorphic and structural evolution of the Vír granulite and surrounding rocks of the Polička Crystalline Unit. Geolines 8: 64-65

Tajčmanová L, Konopásek J, Schulmann K (2001) Metamorphic and structural evolution of the Moldanubian lower crust - an example of the Strážek Moldanubicum. Geolines 13: 119

Tajčmanová L, Verner K, Pertoldová J (2005) Correlation of structural and metamorphic evolution of metamorphic rocks from the Svratka and Polička crystalline complexes. Geolines 19: 112

TajČManová L, KonopáseK J, Schulmann K (2006) Thermal evolution of the orogenic lower crust during exhumation within a thickened Moldanubian root of the Variscan Belt of Central Europe. J Metamorph Geol 24: 119-134

Tномаs WM (1982) Stability relations of the amphibole hastingsite. Am J Sci 282: 136-164

Verner K, Buriánek D, Vrána S., Vondrovic L, Pertoldová J, HANŽL P, NAHODILOVÁ R (2009) Tectonometamorphic features of geological units along the northern periphery of the Moldanubian Zone. J Geosci 54: 87-100

VRána S, Blumel P, Petrakakis K (1995) The Moldanubian Zone in the Czech Republic. In Dallmeyer RD, Franke W, Weber K (eds) Pre-Permian Geology of Central and Eastern Europe. Springer Verlag, Berlin, pp 456-460

White RW, Powell R, Holland TJB, Worley BA (2000) The effect of $\mathrm{TiO}_{2}$ and $\mathrm{Fe}_{2} \mathrm{O}_{3}$ on metapelitic assemblages at greenschist and amphibolite facies conditions: mineral equilibria calculations in the system $\mathrm{K}_{2} \mathrm{O}-\mathrm{FeO}-\mathrm{MgO}-$ $\mathrm{Al}_{2} \mathrm{O}_{3}-\mathrm{SiO}_{2}-\mathrm{H}_{2} \mathrm{O}-\mathrm{TiO}_{2}-\mathrm{Fe}_{2} \mathrm{O}_{3}$. J Metamorph Geol 18: 497-511

Zavřelová A, Melichar R, Verner K (2006) Structural evolution of metagranite from Svratka Crystalline Complex. In: Krmíček L, Pěichystal A, Halavínová M (eds) Moravskoslezské Paleozoikum 2006. Faculty of Science, Masaryk University, Brno, pp 24 (in Czech) 